\title{
Ruas e a ocupação vertical recente: labirintos murados
}

\author{
Streets and recent vertical condos: walled mazes
}

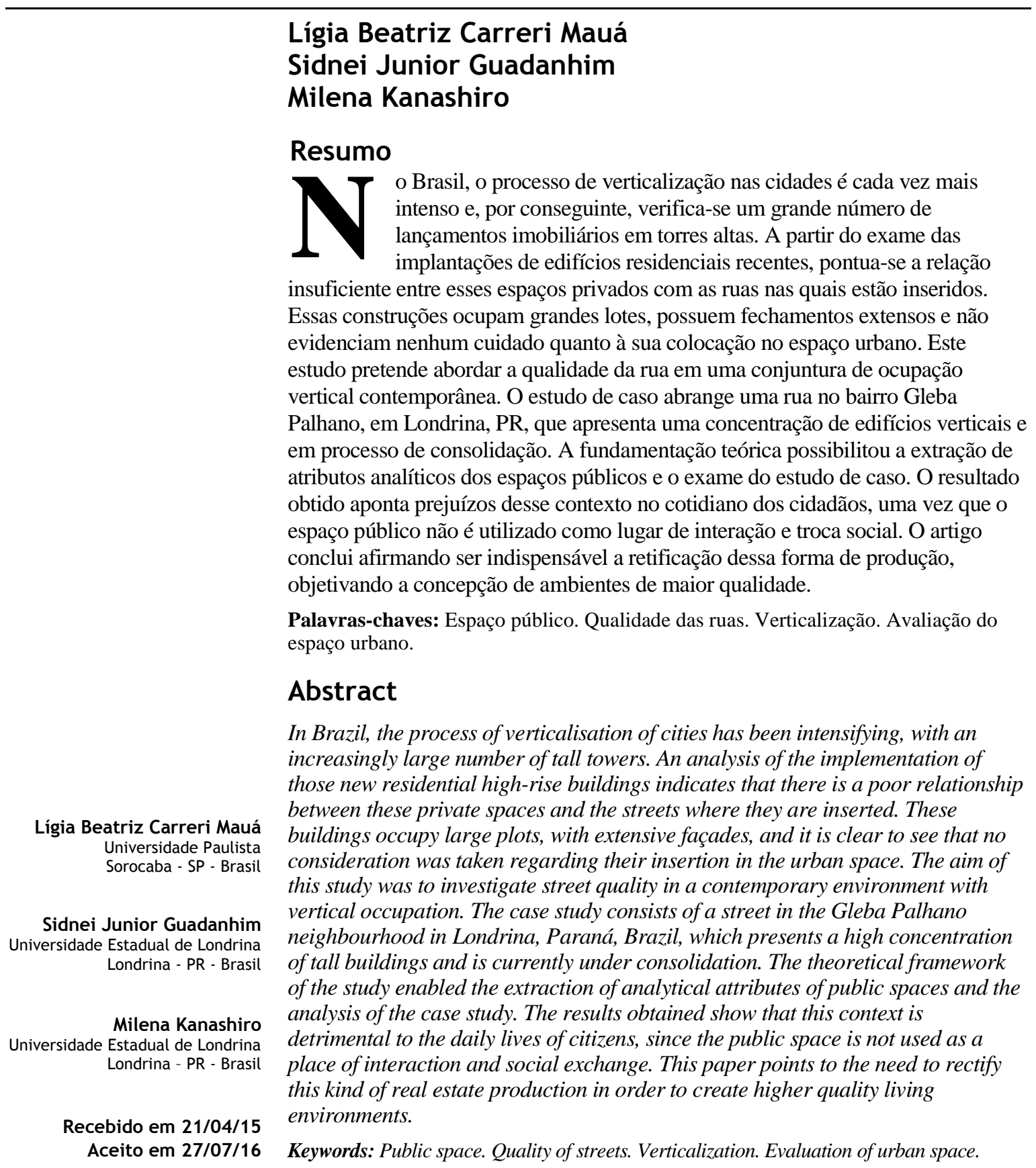




\section{Introdução}

Este estudo refere-se à qualidade do espaço urbano residencial, cujas orientações são sustentadas pelas reflexões relativas ao contexto da produção de habitações coletivas contemporâneas no Brasil e às características resultantes da ocupação vertical, com ênfase na avaliação das ruas e do convívio de seus usuários. Os processos de verticalização são vivenciados por um número cada vez maior de cidades (IBGE, 2010). Portanto, considera-se importante analisar a rua em uma condição em que a ocupação vertical atual se faz presente.

A produção recente de habitações verticalizadas nas cidades nacionais demonstra um modelo predominante de implantação, que rejeita sua relação com o espaço público (HOLANDA; KOHLSDORF; KOHLSDORF, 2003; TRAMONTANO, 2006; ALAS, 2013; ALVES, 2013).

Constata-se a grande frequência de empreendimentos residenciais comercializados com apelos de lazer contidos no lote. Em contraponto, há uma ligação insuficiente desses ambientes com as vias públicas nas quais são introduzidos. Obedecendo aos mínimos parâmetros legislativos, os prédios consomem grandes espaços sem associação ao entorno. Em muitas situações, as áreas e os edifícios residenciais não fazem parte de planejamentos municipais, pois são realizados de forma pontual, sem cuidado quanto ao local de sua inserção, tampouco como unidade da cidade e suas consequências (MAUÁ; GUADANHIM, 2014).

As condições de moradia estão intimamente associadas à qualidade de vida de uma comunidade. Os locais onde cidadãos residem e convivem podem ser investigados sob aspectos distintos e em diferentes escalas, abrangendo diversas dimensões da rotina nas cidades - social, econômica e cultural, entre outras. $\mathrm{O}$ movimento e a diversidade de pessoas, as oportunidades de encontros e atividades entre elas, assim como a apropriação do espaço público, possuem relação direta com as áreas de vínculo entre as superfícies edificadas e as ruas. O âmbito social também é resultante do planejamento e da arquitetura de determinado local. Desse modo, faz-se indispensável a investigação dos modos de apropriação das ruas onde a ocupação residencial vertical recentemente se faz presente.

Objetiva-se desenvolver uma discussão sobre a qualidade urbana das ruas em áreas de ocupação vertical à luz da literatura, examinar o uso e os aspectos desses espaços e as inferências da conjuntura apresentada na dimensão pública na utilização e no convívio das ruas e calçadas. Partese de fundamentação teórica para extrair os principais elementos de diagnóstico desses espaços públicos e avalia-se um caso no bairro Gleba Palhano, em Londrina, PR.

Com isso, aponta-se para a rediscussão imprescindível de tal tipologia de construção, dadas as desconsiderações quanto à qualidade espacial dos ambientes públicos resultantes, evidenciando o prosseguimento de um modelo que nega o espaço cotidiano, cuja rua é seu mais importante elemento.

\section{Cidades e verticalização}

A constituição do espaço urbano é resultado de atuações associadas através do tempo, articuladas por agentes de produção e consumo do espaço. Sua compreensão parte de dinâmicas econômicas, sociais e políticas, pois se constitui como zona de investimentos, produção e conflito social, permitindo ser tratada segundo a percepção de seus cidadãos (CORRÊA, 1999).

Explorações a respeito da produção vertical são necessárias, uma vez que definem paisagens urbanas e trazem novos valores de moradia, localização, segurança e infraestrutura. Se antes os processos de verticalização eram observados apenas nas grandes metrópoles, atualmente são verificados na maioria das médias e grandes cidades brasileiras (MORAIS; SILVA; MEDEIROS, 2007).

A verticalização é uma possível ferramenta de promoção de oportunidades para maior número de pessoas residirem em áreas com qualidade urbana (ROLNIK, 2014). Segundo Ramires (1998), tal fenômeno age multiplicando o solo, provocando mudanças morfológicas e funcionais na paisagem e adicionando valor ao território, ampliando seu potencial de aproveitamento. Porém, são necessários debates sobre a interação entre os edifícios com as ruas e imediações. Além de prever a não geração de maiores índices de tráfego veicular, faz-se indispensável que a relação com o entorno e a paisagem não seja descartada. (ROLNIK, 2014).

$\mathrm{Na}$ relação com a rua, as diferenças entre edifícios construídos em São Paulo nos anos 1970 com construções das duas décadas posteriores são pontuadas por Caldeira (2000). Em 1970, os prédios eram comumente abertos ao espaço público, na década seguinte eles passam a ser murados. Anteriormente, as áreas de uso comum restringiam-se a garagens, circulação e,

74 Mauá, L. B. C.; Guadanhim, S. J.; Kanashiro, M. 
ocasionalmente, playground e salão de festas. Atualmente, as unidades de apartamentos possuem áreas cada vez menores, os edifícios passaram a ser comercializados com a inclusão de instalações coletivas de recreação, esportes e lazer. Também justificados pelo aumento da violência, passaram a possuir barreiras como muros, grades, controles de guarita e câmeras (TRAMONTANO, 2006).

\section{Avaliação do espaço público}

As cidades formam conjuntos constituídos por diversos equipamentos, construções, usos e indivíduos. As ruas devem abrigar diferentes dinâmicas e suas especificidades. Dado o seu caráter coletivo, é imperativo que sejam inclusivas, a fim de permitir o acesso dos cidadãos a espaços com qualidade. Por esse motivo, buscou-se um referencial bibliográfico de avaliação do espaço público.

Publicado em 1961, Morte e vida de grandes cidades, de Jane Jacobs, questiona os rumos do planejamento urbano, em uma época em que a herança das convicções modernistas era sentida, apontando a necessidade de apreensão do real funcionamento das cidades em seus atributos socioeconômicos.

Do mesmo modo, Jan Gehl publica, em 1971, Life between buildings: using public space. Nessa obra, a vida entre as edificações é vista como dimensão da arquitetura e do planejamento urbano e, portanto, são apresentados os princípios orientadores de concepção e desenvolvimento de espaços públicos de qualidade.

Amos Rapoport, no capítulo La importância y la natureza de la percepción ambiental da obra Aspectos humanos de la forma urbana. Hacia uma confrontación de las Ciencias Sociales com el diseño de la forma urbana, de 1977, constrói uma narrativa sobre as relações do ambiente construído com a cultura e estrutura mental das pessoas; concepção do meio ambiente a partir da interação com o indivíduo.

Os estudos apresentados no livro The Social Life of Small Urban Spaces são o resultado de uma pesquisa realizada por W. H. Whyte na década de 1970. A análise buscou as razões pelas quais alguns espaços públicos urbanos da cidade de Nova Iorque funcionavam e outros não, e quais lições podem ser aprendidas.

Donald Appleyard apresenta métodos de controle de tráfego e estratégias de análise e proteção de bairros em seu trabalho Livable Streets (1981). Dentro da separação de ruas pelo nível de tráfego, Appleyard define estratégias para garantia de atratividade e diminuição de problemas para cada uma.

A obra de Ian Bentley et al. (1999), Responsive environments: a manual for designers, publicada em 1985, apresenta orientações projetuais e demonstrações de como transpor ideais na construção de espaços, com o intuito de realizar ambientes democráticos com vitalidade.

A monotonia dos espaços públicos consiste em preocupação para os autores supracitados. Jacobs (2000) entende que, se o contato entre os habitantes fosse reduzido à convivência privada, a cidade seria inútil. A privatização da vida pública é vista por Gehl (2011) como consequência da dispersão de pessoas, ausência de movimento e atividades, tornando a cidade vazia, monótona e mais perigosa. Já Whyte (1980) cita como exemplo de monotonia edifícios onde em vez do comércio variado em seu térreo encontram-se fachadas envidraçadas de um único uso. Carmona, Heath e Tiesdell (2010) reúnem contribuições práticas e teóricas do desenho urbano a partir do exame de estudos internacionais no livro Public places urban spaces: the dimensions of urban design, publicado em 2003. A obra procura elucidar como o desenho urbano afeta o cotidiano dos lugares.

\section{Percursos de investigação}

Dado o objeto de pesquisa - ruas em áreas atuais de ocupação vertical residencial - objetiva-se a discussão da qualidade desses espaços dentro do âmbito social de uso e do convívio das pessoas. Enxerga-se a necessidade de investigação das consequências dos ambientes construídos sobre as ruas nos quais estão inseridos, por meio do sustentáculo teórico anteriormente apresentado. Para tal averiguação, definiu-se o método de estudo de caso (YIN, 2001), que possibilita o diagnóstico de um local com a existência das propriedades salientadas. O bairro Gleba Palhano, na cidade de Londrina, constitui uma realidade em que é possível presenciar áreas concentradas de verticalização. O local possui grande número de torres residenciais e começa a ser alvo de reportagens locais que tratam problemas de tráfego causados pela alta densidade de moradores e, principalmente, pela escassez de áreas públicas nas proximidades (JORNAL DA GLEBA, 2013, 2015; JORNAL DE LONDRINA, 2013, 2014).

Conforme o andamento da pesquisa, a fundamentação teórica definiu uma listagem de qualidades recomendadas para as ruas. Ressalta-se o entendimento do contexto divergente dessa literatura prescritiva internacional. Contudo, tal discussão é observada em pesquisas brasileiras, visto que o surgimento das críticas relaciona-se 
com a discussão do planejamento urbano não somente como premissa física, mas indissociável das questões sociais e de uso do espaço cotidiano.

O método de estudo de caso orienta estratégias para avaliação de uma rua em área de verticalização recente. Para tanto, definiu-se a área para investigação e avaliação das qualidades recomendadas. Foram realizadas pesquisas sobre o histórico de conformação da área, coleta de dados censitários, perfil da população residente e aspectos legislativos. Por fim, a avaliação da maior parte das recomendações foi possível a partir da observação sistemática do espaço in loco, recorrendo-se às anotações, aos registros, aos mapeamentos e à contagem de veículos e pessoas a fim de obter os dados para mensuração. As observações e contagem em campo foram realizadas em três dias: sábado, domingo e quartafeira, compreendendo o período entre $7 \mathrm{~h} 30 \mathrm{~min}$ e 19h30min. Tal sistematização permitiu o diagnóstico de informações que tornassem possível a exploração do fenômeno em estudo.

\section{Gleba Palhano: a paisagem consolidada de uma área em processo de ocupação}

A área estudada (Figura 1) manteve-se como vazio urbano até o início da década de 1990, constituindo parte da Fazenda Palhano, demarcada anteriormente à fundação da cidade de Londrina. Mábio Palhano, comissário de terras do estado para o norte do Paraná, realizou as primeiras expedições para demarcação de terrenos na região, antes de 1929. Após sua morte, seu filho herdou 750 alqueires de uma fazenda, área contígua à cidade e que já possuía sítios e patrimônios em parcelamentos e loteamentos em chácaras. A Fazenda Palhano, fracionada pela Lei Municipal n. 1.794, em 1971, permaneceu em divisões que se conservaram sem alterações e construções até 1992 (SILVA; CARVALHO, 2013).

Figura 1 - Mapa de Londrina - área do estudo de caso (vermelho) e quadrilátero inicial da cidade (azul)

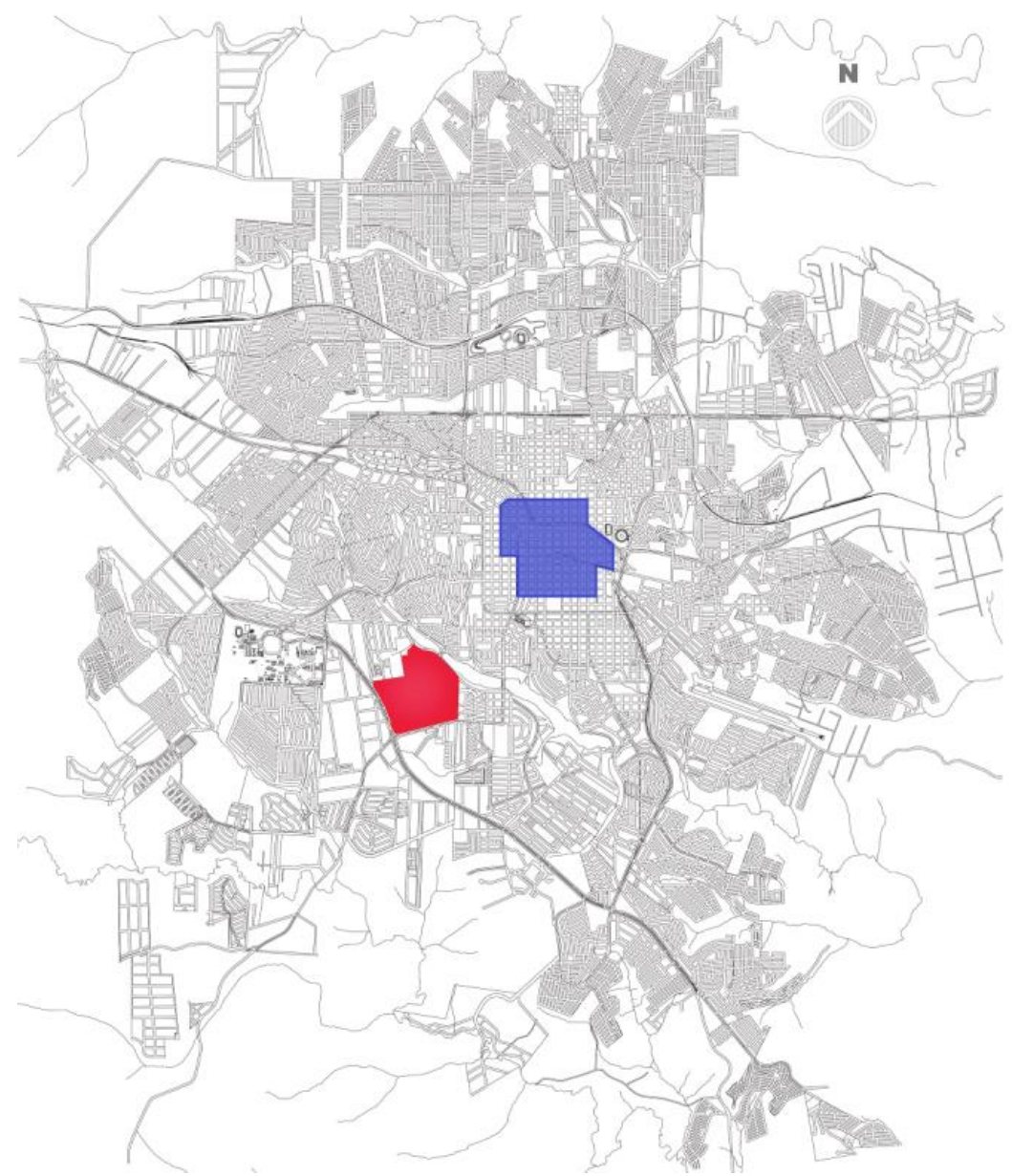

Fonte: adaptado de Instituto de Pesquisa e Planejamento Urbano de Londrina (2014).

76 Mauá, L. B. C.; Guadanhim, S. J.; Kanashiro, M. 
O espaço, que até o início da década de 1990 se caracterizava como área predominantemente rural, passou a sofrer transformações após a efetuação de obras viárias pelo poder público e a inserção de um shopping. A partir da inauguração do Catuaí Shopping Center em 1990 e da implantação de infraestrutura da área, surgiram loteamentos fechados de condomínios horizontais e verticais em suas proximidades e a inserção de equipamentos, como dois campi de universidades privadas (SILVA, 2007). O shopping firmou-se como centralidade, interferindo nos fluxos dos cidadãos. Os arranjos espaciais em questão tiveram interferência da incorporação imobiliária, na modificação dos valores da qualidade de vida, na busca de bem-estar e segurança a partir do afastamento do centro principal (SILVA, 2007).

A introdução de condomínios verticais na atual região da Gleba Palhano (Figura 2) consolida uma tipologia de construção que multiplica os lucros dos empreendimentos, cuja geração deu-se a partir do estabelecimento do centro comercial e da apropriação da proximidade com o Lago Igapó II, utilizado como arma mercadológica para venda de edifícios na área, já que é um equipamento comumente relacionado à paisagem.

Essas edificações asseguram uma área que partiu do estabelecimento de uma nova centralidade, o shopping, e se constitui conforme o poder aquisitivo do consumidor de um espaço que comportou e ainda comporta alta valorização articulada pelos promotores imobiliários.

\section{Qualidades recomendadas e a Rua Caracas}

A região estudada da Gleba Palhano compreende a área que conforma a paisagem verticalizada entre o Lago Igapó II, a Avenida Madre Leônia Milito e a Rodovia PR-445. Para a aplicação de instrumentos de levantamento em campo, julgou-se necessária a seleção de ruas consolidadas em ambos os lados, onde não houvesse presença de lotes desocupados, uma vez que as formas de ocupação interferem neste estudo. Seguindo os critérios apontados, constataram-se três vias onde os limites com os lados de quadras possuíssem todos os lotes ocupados. O trecho da Rua Caracas (Figura 3) foi selecionado para aplicação dos levantamentos deste trabalho por apresentar maior diversidade entre os anos de conclusão dos edifícios do local.

Os autores estudados analisam uma variedade de aspectos positivos e negativos às cidades. Destacase a importância do contato entre os habitantes, pois se as atividades nas ruas são inexistentes, as comunicações também desaparecem. Whyte (1980) pontua a falha do design dos espaços livres em limitar lugares que poderiam abrigar a vida urbana positivamente. Carmona, Heath e Tiesdell (2010) acrescentam, por sua vez, que a falta de preocupação com as ruas entre os edifícios ocasionou a ausência de combinações entre edificação e suas inserções, fazendo dos espaços mero acréscimo dos edifícios.

No processo de reunião desses conhecimentos, foram gerados aspectos-síntese, que se relacionam com as afirmações dos autores e permitem identificar qualidades recomendadas para as ruas (Figura 4). Em uma primeira análise do estudo de caso, verifica-se a correlação entre as recomendações e a possibilidade de agrupamentos em quatro dimensões analíticas: usos, deslocamentos, usuários e visuais.

Assim, pode-se afirmar que o local configura uma área basicamente de um único caráter: residencial vertical (Figura 5), na qual os estabelecimentos comerciais estão localizados em avenidas que concentram o fluxo veicular de passagem ao shopping e à zona sul da cidade e não do interior da área e suas unidades habitacionais (Figura 6). Essa configuração é oposta às recomendações nas quais a diversidade comercial e a variedade de usos associam-se à garantia de benefícios econômicos e proximidade de atividades aos residentes, fomentando vitalidade e segurança natural das ruas (JACOBS, 2000; CARMONA; HEATH; TIESDELL, 2010).

Figura 2 - Gleba Palhano

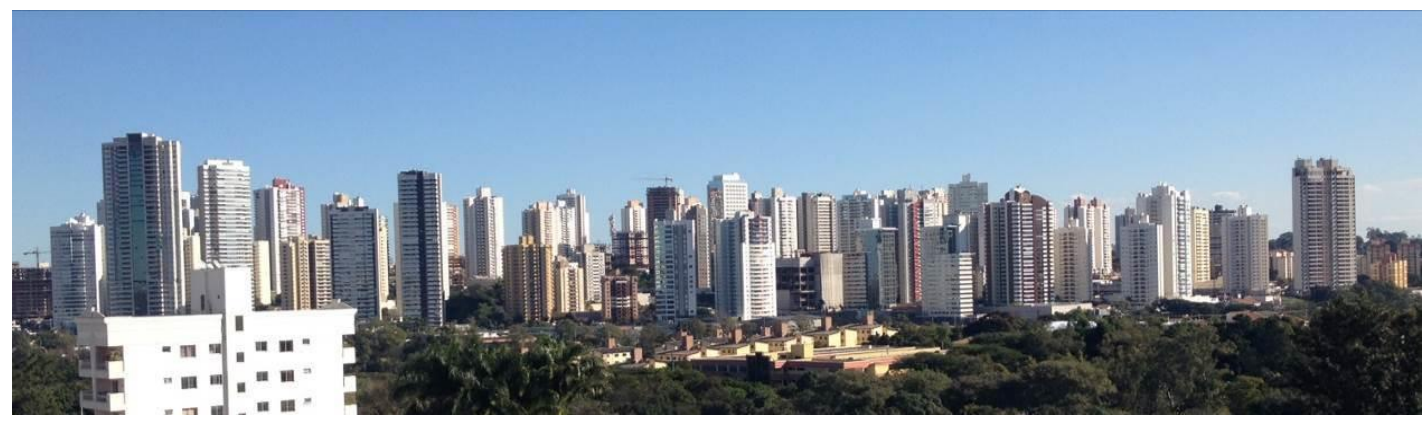

Fonte: Mauá (2015). 
Figura 3 - Foto aérea da área

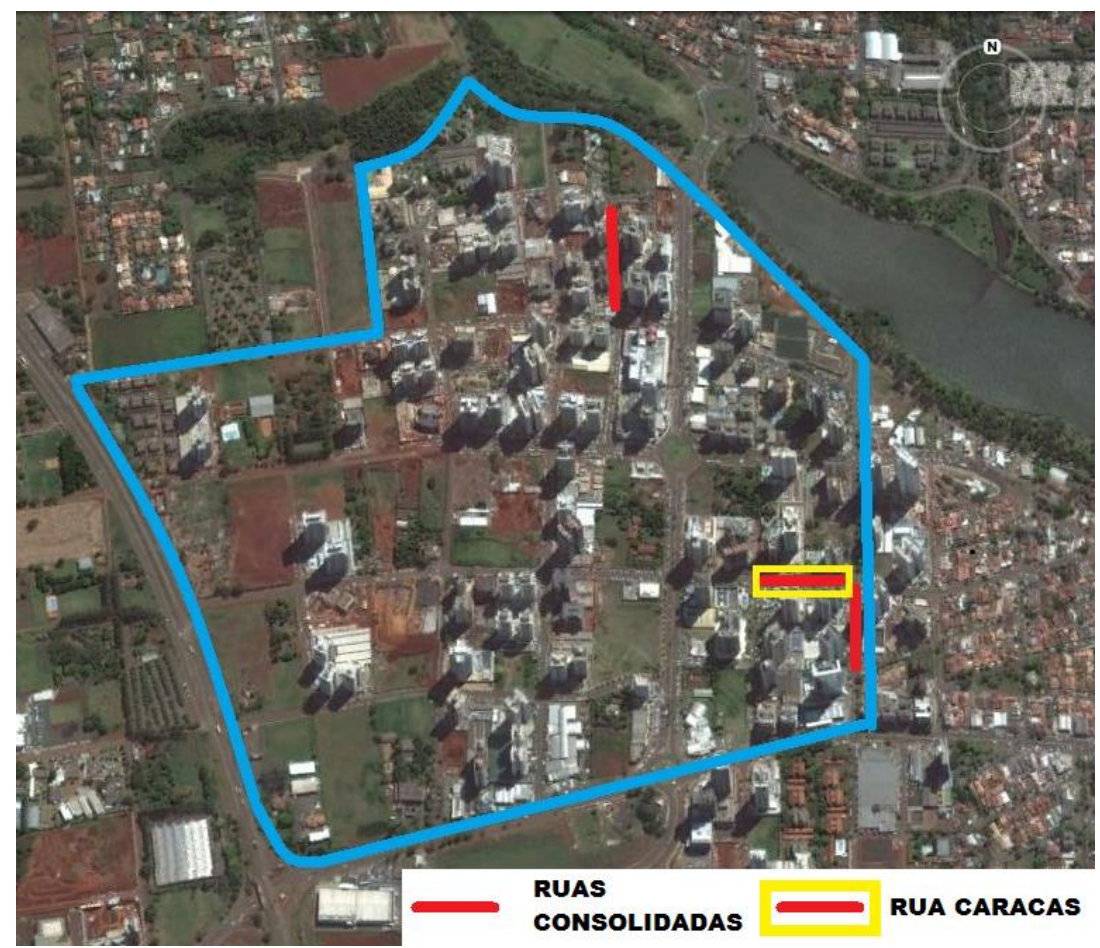

Fonte: Mauá (2015).

Figura 4 - Quadro síntese: dimensões - qualidades recomendadas

\begin{tabular}{|c|c|c|c|c|c|c|c|c|}
\hline & \multicolumn{8}{|c|}{ QUADRO SÍNTESE: DIMENSÕES - QUALIDADES RECOMENDADAS } \\
\hline & \multirow[b]{2}{*}{ QUALIDADES RECOMENDADAS } & \multicolumn{7}{|c|}{$\begin{array}{ll}\text { AUTORES } \\
\end{array}$} \\
\hline & & $\begin{array}{l}\text { JACOBS } \\
\text { (1961) }\end{array}$ & $\begin{array}{c}\text { GEHL } \\
\text { (1971) }\end{array}$ & \begin{tabular}{|c|} 
RAPOPORT \\
(1977)
\end{tabular} & $\begin{array}{l}\text { WHYTE } \\
\text { (1980) }\end{array}$ & \begin{tabular}{|c|} 
APPLEYARD \\
(1981)
\end{tabular} & $\begin{array}{l}\text { BENTLEY } \\
\text { (1985) }\end{array}$ & $\begin{array}{l}\text { CARMONA } \\
\text { (2003) }\end{array}$ \\
\hline \multirow{6}{*}{$\begin{array}{l}\text { Do } \\
\text { Sp } \\
\end{array}$} & Variedade de usos & & & & & & & \\
\hline & Diversidade comercial & & & & & & & \\
\hline & Existência de edifícios públicos & & & & & & & \\
\hline & Proximidade a espaços livres de lazer & & & & & & & \\
\hline & Não privatização de espaços públicos & & & & & & & \\
\hline & Trabalho e recreação próximos às residências & & & & & & & \\
\hline \multirow{6}{*}{ 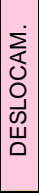 } & Combinação de diferentes arranjos de quadras & & & & & & & \\
\hline & Conectividade do tecido das ruas & & & & & & & \\
\hline & Multiplicidade de caminhos possíveis & & & & & & & \\
\hline & Distâncias confortáveis para andar & & & & & & & \\
\hline & Acessibilidade e mobilidade ao público & & & & & & & \\
\hline & Transporte público eficiente & & & & & & & \\
\hline \multirow{4}{*}{ 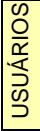 } & Densidade de pessoas nas ruas & & & & & & & \\
\hline & Variedade de usuários & & & & & & & \\
\hline & Presença de crianças e idosos & & & & & & & \\
\hline & Suporte a movimento em diferentes horários & & & & & & & \\
\hline & Variedade tipos de edifícios & & & & & & & \\
\hline & Riqueza visual perceptível & & & & & & & \\
\hline & Boa visibilidade & & & & & & & \\
\hline & Limites bem definidos entre espaços púb./ priv. & & & & & & & \\
\hline & Correlação entre espaços internores e exteriores & & & & & & & \\
\hline & Fachadas ativas & & & & & & & \\
\hline \multirow{9}{*}{ 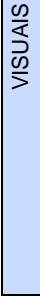 } & Fechamentos permeáveis & & & & & & & \\
\hline & Fácil acesso às aberturas & & & & & & & \\
\hline & Calçadas com mais espaço & & & & & & & \\
\hline & Locais para sentar e estar & & & & & & & \\
\hline & Acomodação de mobiliário urbano & & & & & & & \\
\hline & Calçadas com vegetação & & & & & & & \\
\hline & Boa iluminação (natural e artificial) & & & & & & & \\
\hline & Boa ventilação (evitar efeito túnel) & & & & & & & \\
\hline & Não murar esquinas & & & & & & & \\
\hline
\end{tabular}

Fonte: Mauá (2015).

78 Mauá, L. B. C.; Guadanhim, S. J.; Kanashiro, M. 
Figura 5 - Diversidade de usos

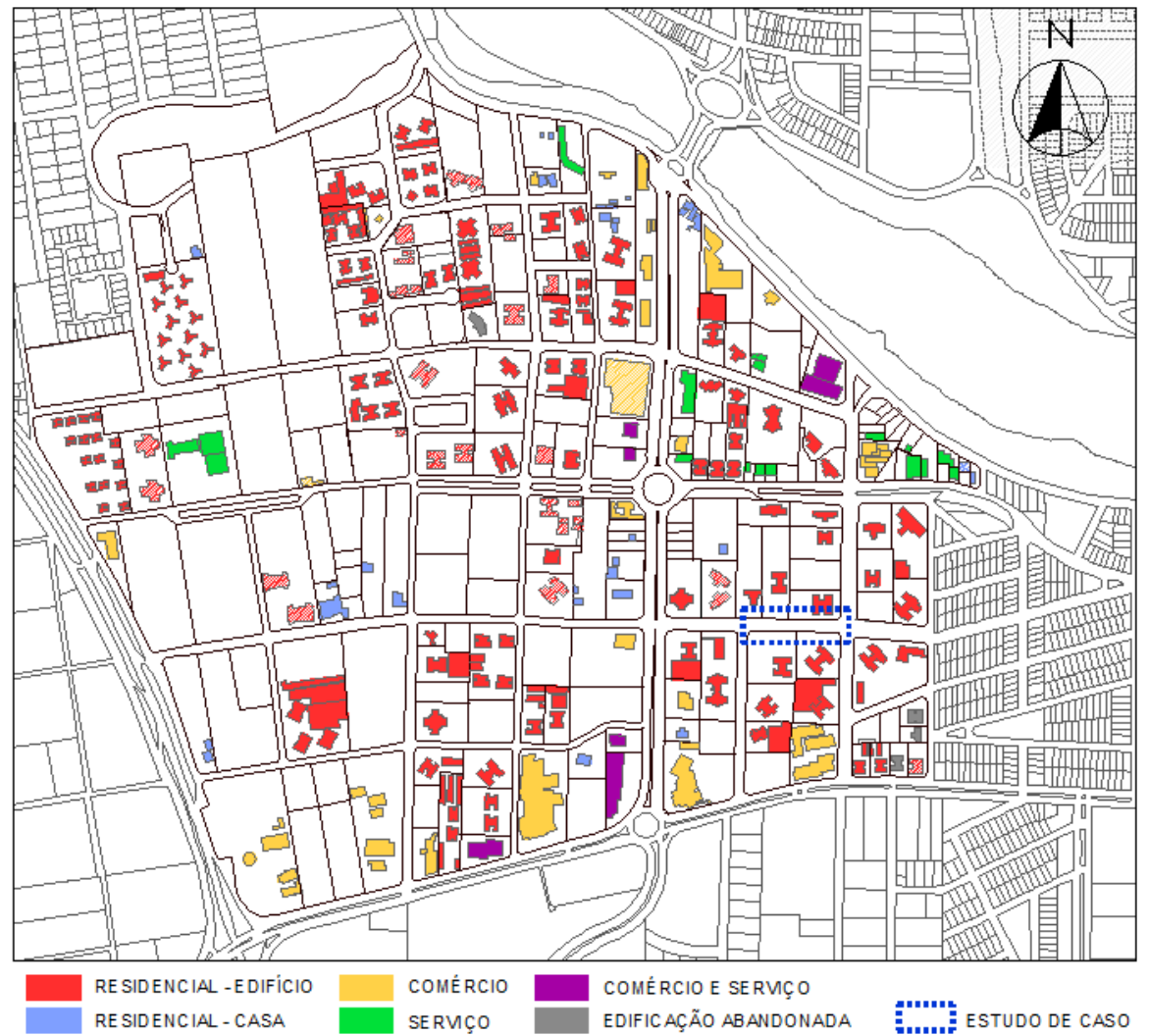

Fonte: Mauá (2015).

Figura 6 - Vias próximas

Fonte: Mauá (2015).

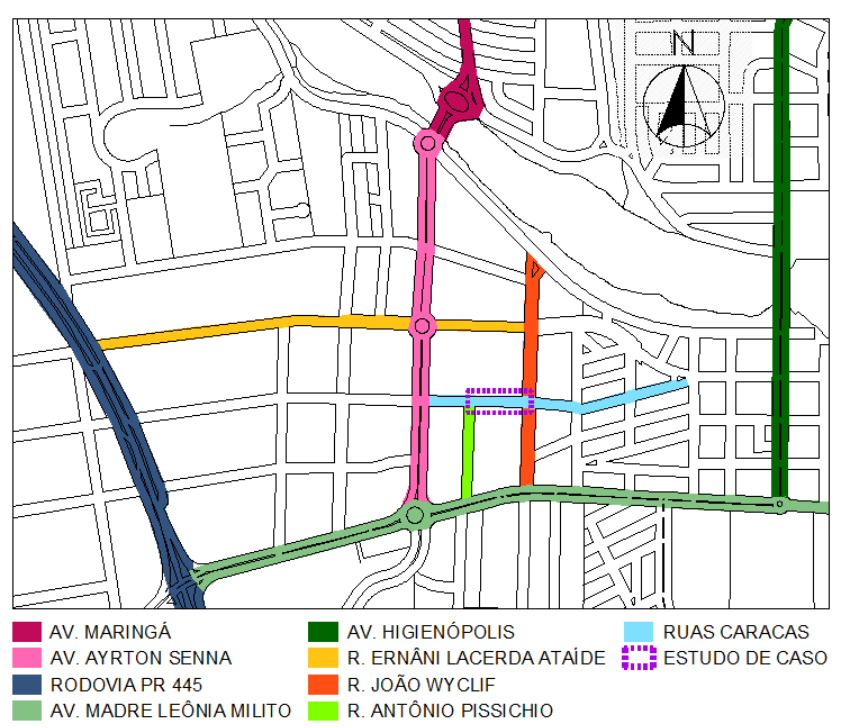

\section{Dimensão de análise: usos}

A análise de usos está correlacionada com as recomendações de Jacobs (2000), Gehl (2011) e Carmona, Heath e Tiesdekk (2010) no destaque da importância pela diversidade comercial nas áreas, como garantia de utilização do espaço público, movimento e vitalidade.

Os térreos das torres comerciais também rejeitam o contato com as ruas, uma vez que possuem superfícies fechadas, entradas controladas e, por vezes, taludes (Figura 7). 
A área não possui edifícios públicos, um fator que poderia contribuir para a variedade de usos e conformação de espaços convidativos. Observa-se também a tendência por áreas privatizadas de uso comum: os térreos dos lotes dos edifícios residenciais constituem-se em áreas comuns de lazer dos moradores e ocasionam o fechamento nos limites das ruas.

Os espaços livres que atendem a área estão demonstrados no mapa a seguir e compreendem a Praça Pé Vermelho, a área do aterro e o Lago Igapó II. A praça mantém-se isolada, somente como espaço de integração dos edifícios adjacentes, não sendo significativa para o estudo de caso. $\mathrm{O}$ aterro consiste em uma extensa área de fundo de vale localizada entre o Lago Igapó II e o Lago Igapó III.

Para as análises de espaços livres de lazer como polos de atração, foram levantados os dados referentes à quantidade e direção do fluxo de pessoas (Figuras 8 e 9) para esses espaços públicos (Figura 10), inferindo no desenvolvimento de atividades de lazer ou de esporte. Esse tipo de atividade é caracterizado por Gehl (2011) como opcional, com ações que compreendem atividades de lazer e de descanso. As Figuras 11 e 12 demonstram o número de pessoas em atividades associadas aos espaços livres de lazer (usando roupa esportiva, bicicleta e patinete, e praticando corrida) e o quantitativo de pedestres que passaram por essas direções.

A leitura dos gráficos revela que o fluxo de pessoas na rua é baixo. Dentro dessa amostragem, aqueles que utilizam o espaço público para atividades opcionais são significativamente em menor número.

Figura 7 - Térreo edifício comercial na Av. Ayrton S. da Silva

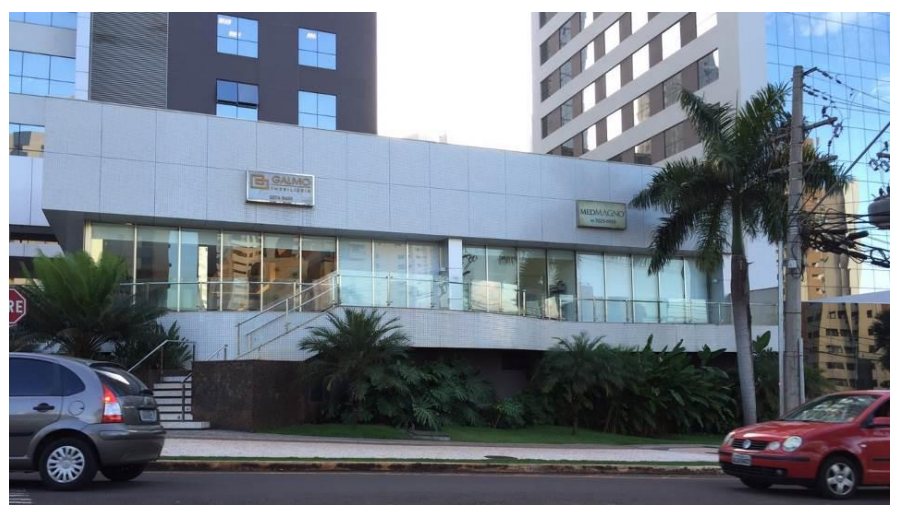

Fonte: Mauá (2015).

Figura 8 - Percursos do fluxo da R. João Wyclif para R. Antônio Pissicchio

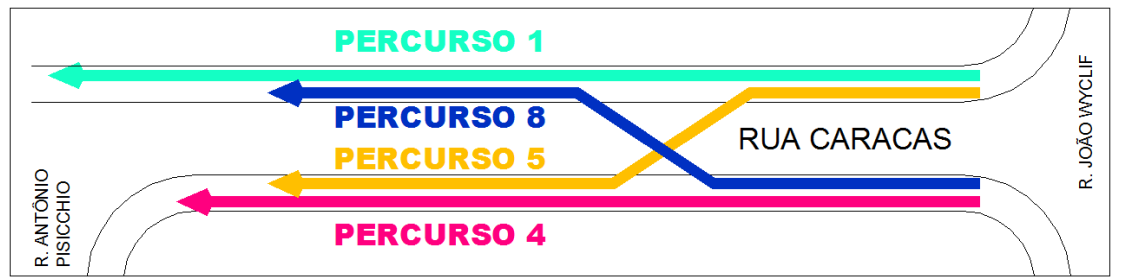

Fonte: Mauá (2015).

Figura 9 - Percursos do fluxo da R. Antônio Pisicchio para R. João Wyclif

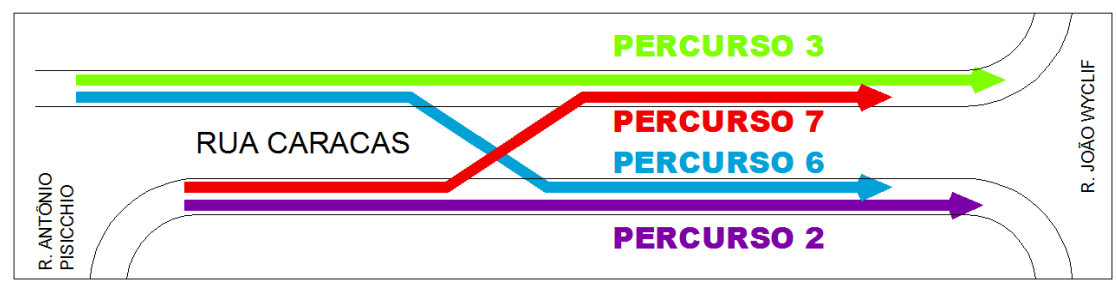

Fonte: Mauá (2015).

80 Mauá, L. B. C.; Guadanhim, S. J.; Kanashiro, M. 
Figura 10 - Espaços livres de lazer

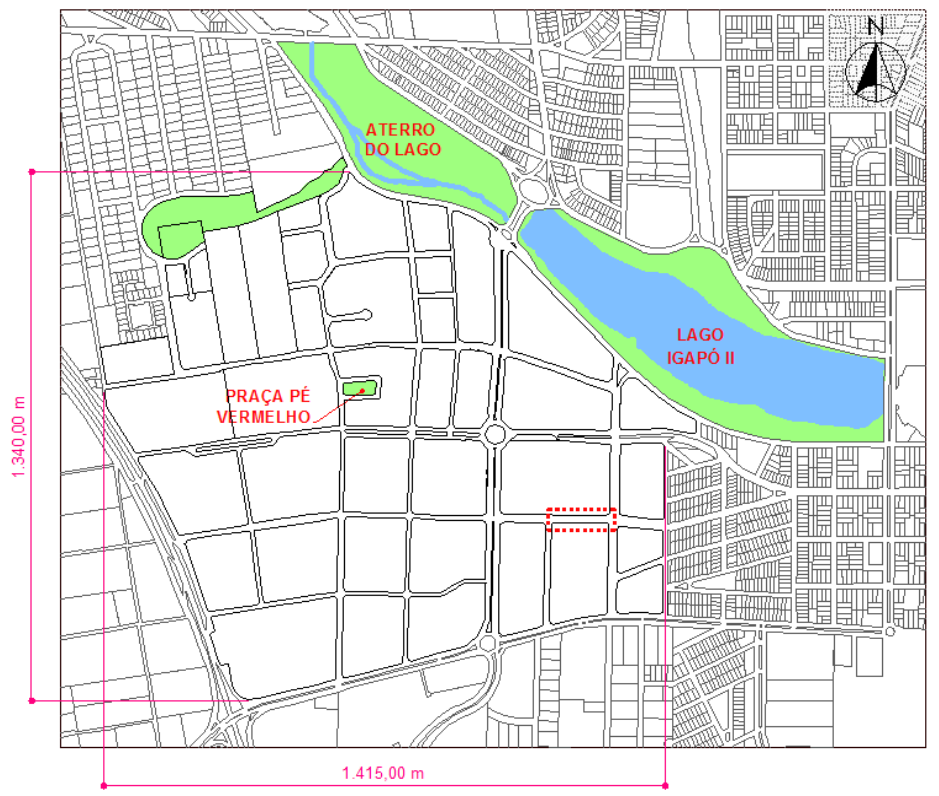

Fonte: Mauá (2015).

Figura 11 - Atividades opcionais nos percursos 1, 4, 5 e 8

Percursos $1,4,5$ e 8

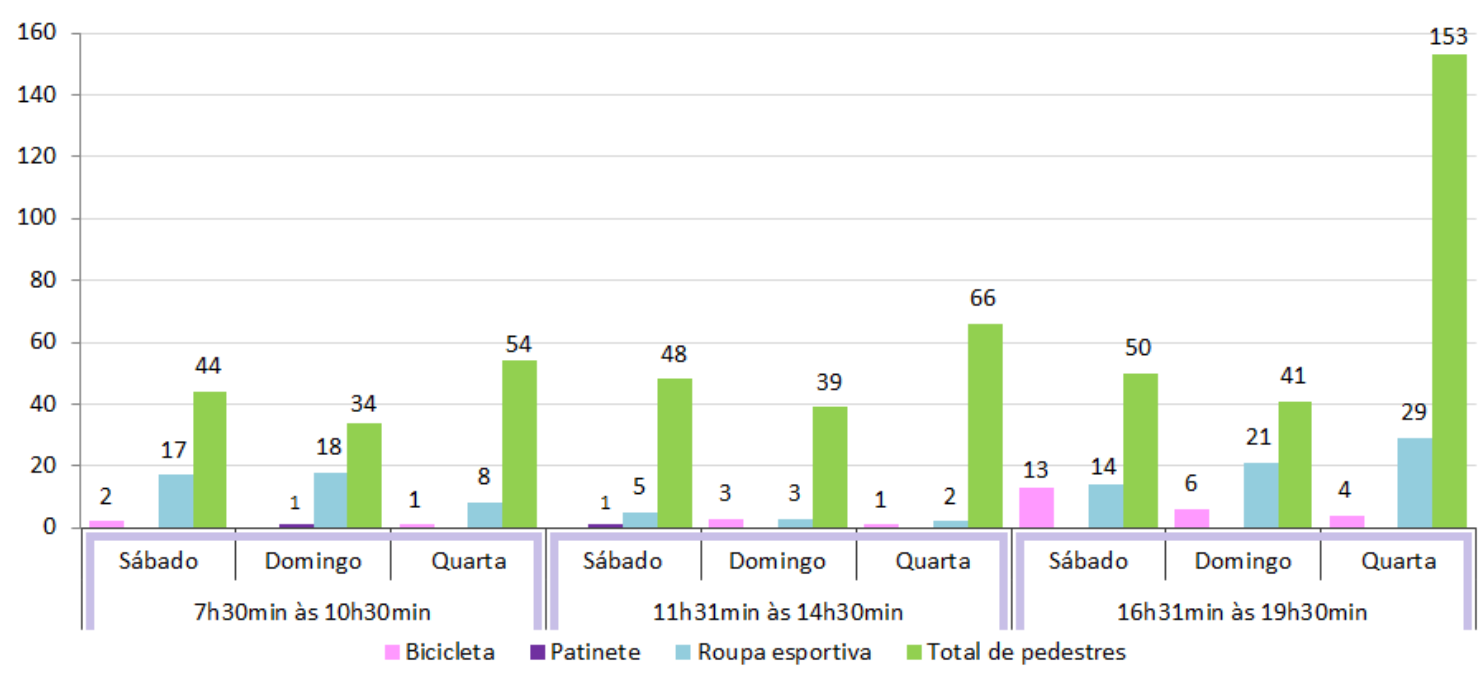

Fonte: Mauá (2015). 
Figura 12 - Atividades opcionais nos percursos 2, 3, 6 e 7

Percurso 2, 3, 6, 7

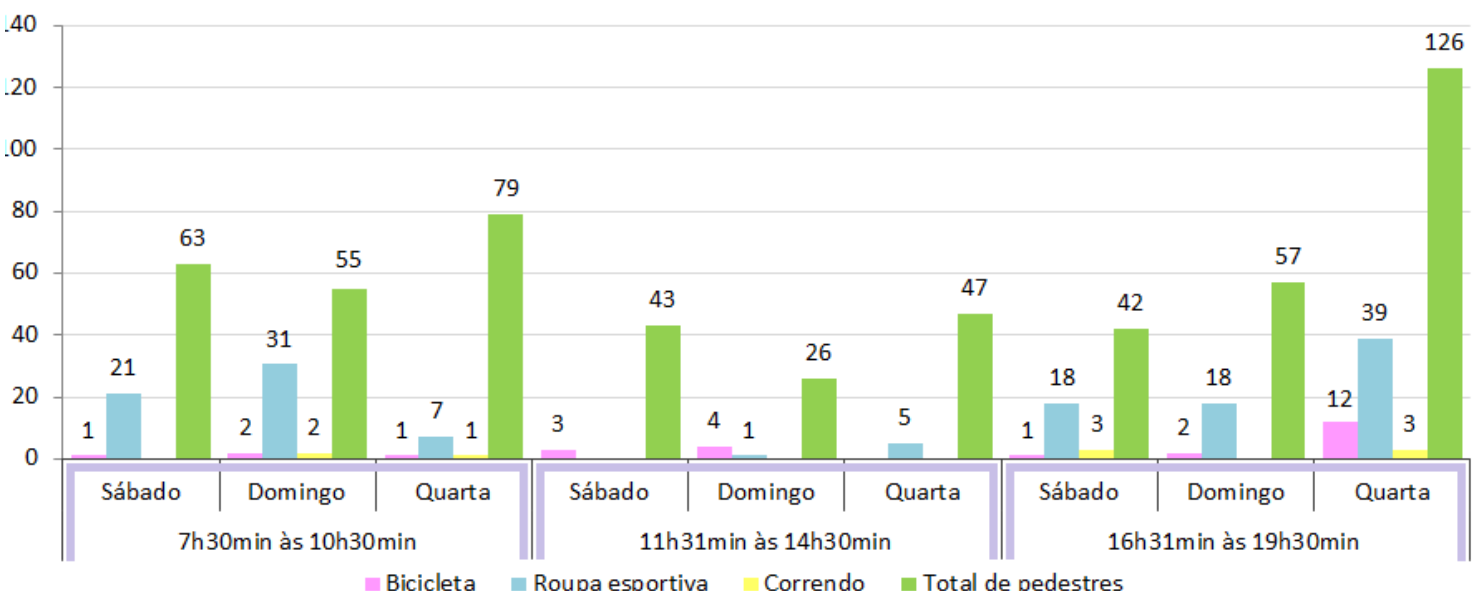

Fonte: Mauá (2015).

Consideram-se os argumentos de Bentley et al. (1999) da complementaridade entre áreas públicas e privadas como garantia da diversidade de alternativas e de Jacobs (2000) para a existência da multiplicidade de atividades e escolhas em áreas residenciais. Verifica-se um único espaço para o desenvolvimento das atividades opcionais do local.

Com objetivo de avaliar a qualidade referente ao trabalho e à recreação próximos às residências da Rua Caracas, foi realizada a contagem de pedestres, veículos (e respectivo direcionamento) e quantidade de automóveis que estacionaram na rua. Os veículos foram separados de acordo com a direção (Figura 13): aqueles que se dirigiram à Rua João Wyclif foram marcados como "veículos para centro" e aqueles em direção à Avenida Ayrton Senna ou à Rua Antônio Pisicchio, foram marcados como "veículos para shopping”. Não é possível saber ao certo seu destino, mas considerou-se essa marcação para efeito de análise. A direção ao centro sugere como destino as regiões norte, oeste e leste, já a direção ao shopping indica o direcionamento para a região sul da cidade - ver Figura 1.

O movimento veicular da Rua Caracas é expressivamente maior que o de pedestres. Nota-se no primeiro horário dos três dias que a quantidade de veículos em direção ao centro é maior, e nos outros horários a quantidade de veículos que se movem em direção ao shopping é mais expressiva.

Em sua maioria, o primeiro horário representa o fluxo de pessoas em direção às suas atividades. Já o segundo, o horário de almoço, e o último, fim da tarde, representam o retorno às moradias. É possível apontar que na quarta-feira os residentes da Gleba Palhano e proximidades do shopping rumam em direção ao centro para trabalhar, retornando no fim do dia. A semelhança de números no horário intermediário sugere a chegada para almoço e retorno ao trabalho.

Para Jacobs (2000), em áreas com predomínio do uso residencial deve existir variedade, proximidade e mescla entre circulações e locais de trabalho para abrigar maior movimento de pedestre. A análise efetuada ressalta o oposto do que é defendido por Carmona, Heath e Tiesdell (2010) no que se refere à qualidade espacial: certa organização de autossuficiência para redução de veículos e aumento de pedestres.

\section{Dimensão de análise: deslocamentos}

Pessoas deslocam-se para locais com vida, escolhendo participar da cidade, elegendo espaços que abriguem interação social, intersecções de caminhos ou pontos próximos a estes (WHYTE, 1980). A dispersão de pessoas suspende os controles naturais de manutenção de segurança, consequências de padrões espontâneos de comportamento (JACOBS, 2000).

São observados poucos vestígios de manifestação e participação social nas ruas, apesar da diversidade do padrão de quadra que em geral são muito extensas (Figura 10). Na perspectiva do movimento pedestre, ressalta-se que tais extensões de quadras não são compatíveis com uma permeabilidade satisfatória ao transeunte. As subdivisões em lotes extensos com fachadas inativas acrescentam uma percepção negativa. 
Figura 13 - Direções veículos e pedestres

Direções veículos e pedestres

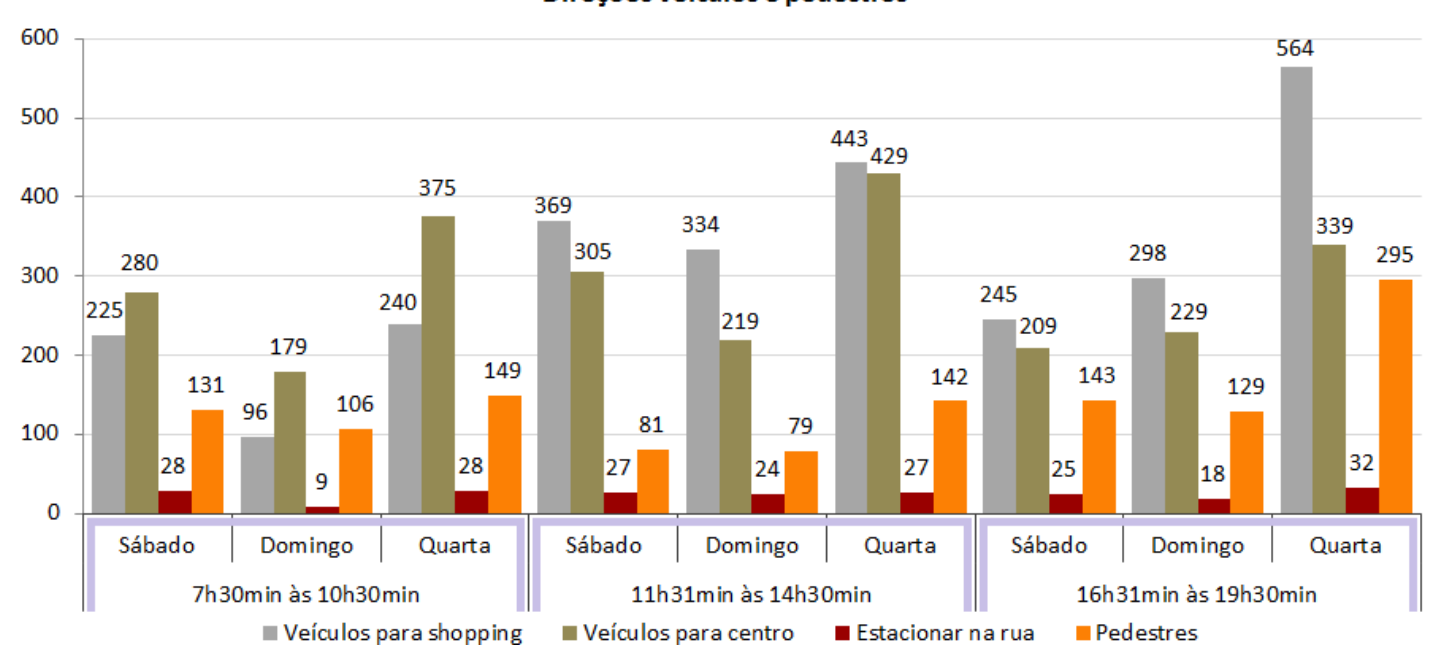

Fonte: Mauá (2015).

Figura 14 - Arranjos de quadras

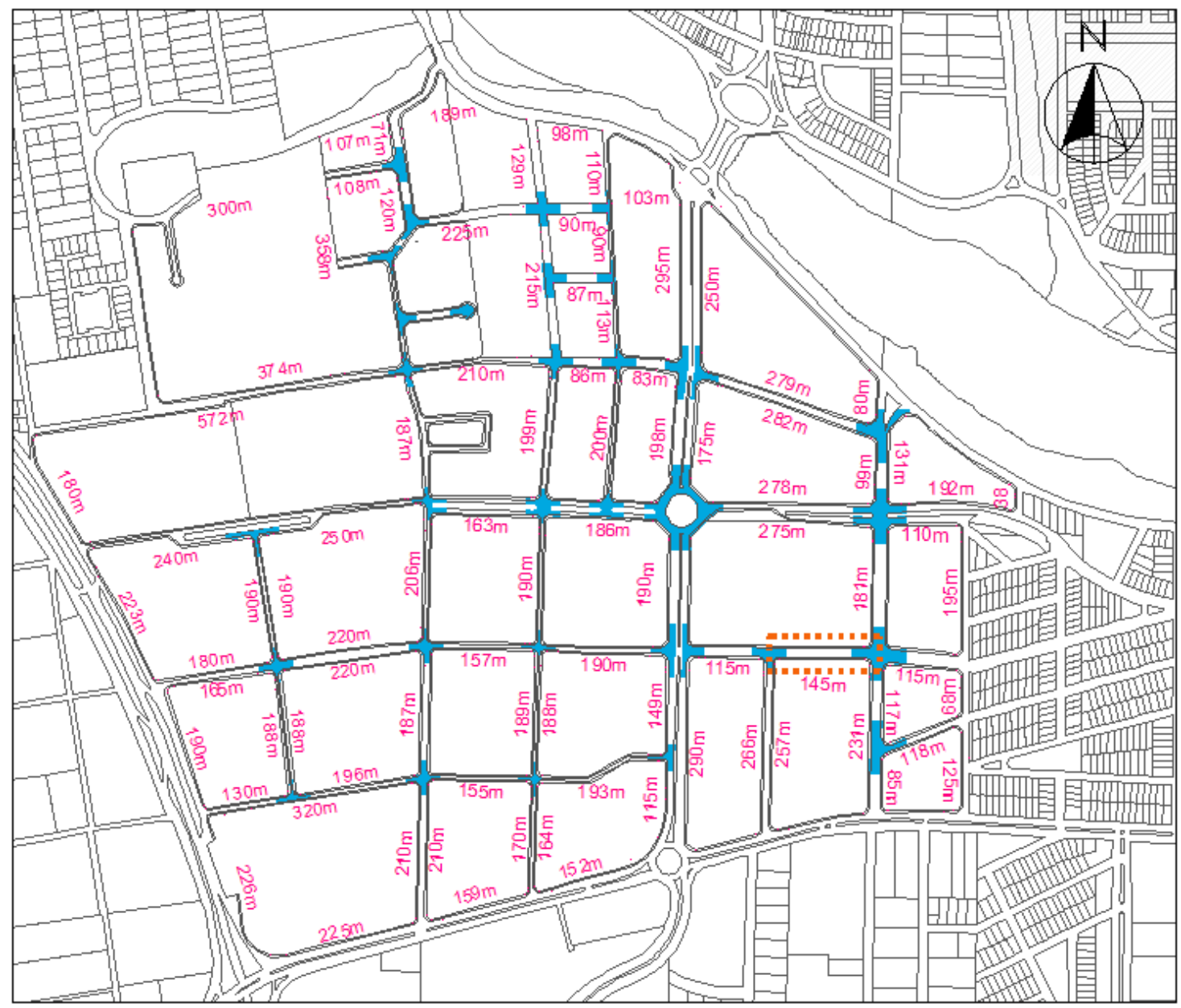

Fonte: Mauá (2015). 
Comércios e serviços estão locados em vias que deverão concentrar cada vez mais tráfego e necessidade por áreas de estacionamento como consequência do uso comercial. Na Av. Ayrton Senna, os pedestres chegam a esperar alguns minutos para conseguir atravessar (Figura 15) e ainda enfrentam riscos decorrentes de um trânsito em alta velocidade (JORNAL DE LONDRINA, 2014).

A área conformou-se como espaço da cidade para "utilização de carros". Na questão da eficiência do transporte público, cabe ressaltar que as pessoas que utilizam as linhas de ônibus, em sua maioria, são prestadores de serviços que circulam dentro desse perímetro a pé. Na Gleba Palhano, as áreas mais afastadas dos pontos de ônibus estão dentro dos limites de distâncias confortáveis para andar (Figura 16). Por meio de coleta de dados, constatou-se que há um bom número de linhas de ônibus que atendem a área e as localizações dos pontos de ônibus abrangem-na em sua totalidade.

A declividade é outro elemento que interfere nas condições de caminhada, além das quadras extensas. Observa-se na Figura 17 que a área possui declividade acentuada, fator que gera desconforto ao pedestre.

\section{Figura 15 - Pedestre atravessando a Av. Ayrton Senna da Silva}

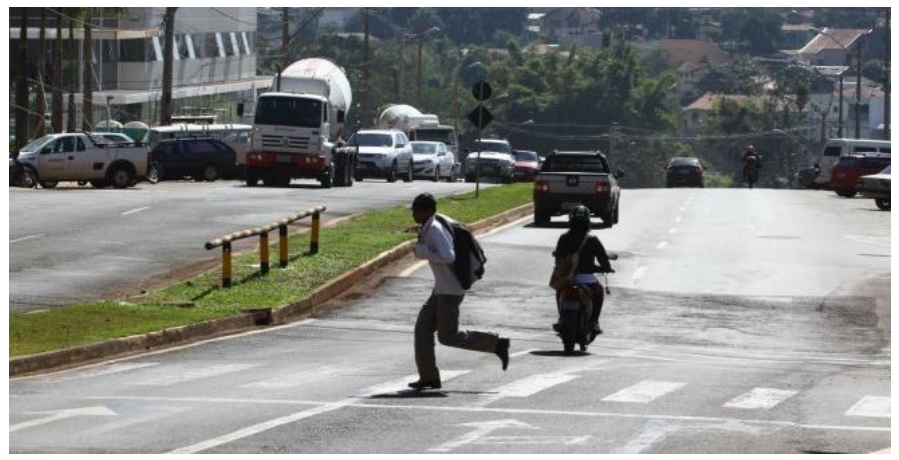

Fonte: Custódio (2014).

Figura 16 - Percursos das linhas de ônibus

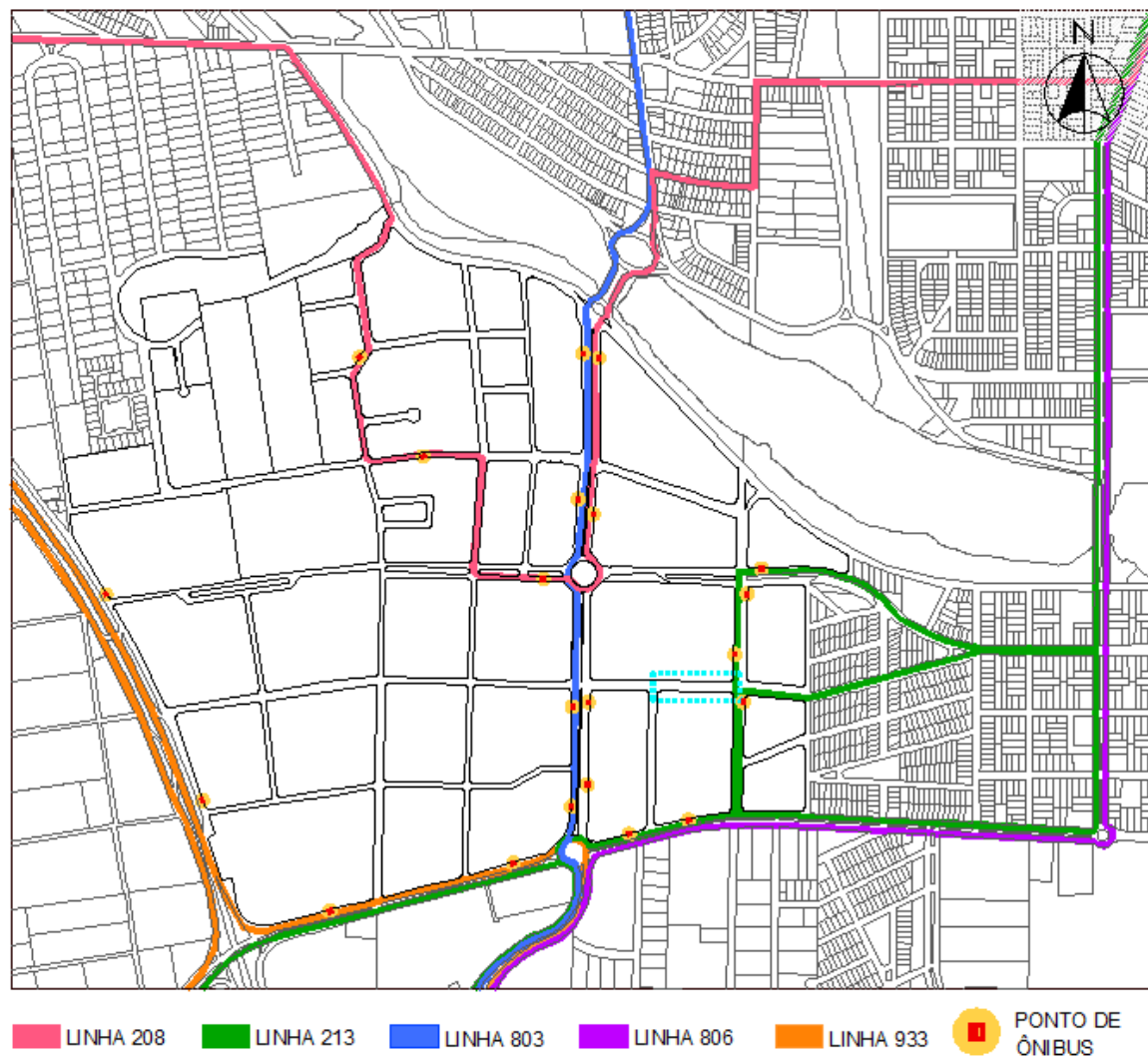

Fonte: Mauá (2015).

84 Mauá, L. B. C.; Guadanhim, S. J.; Kanashiro, M. 
Figura 17 - Declividade

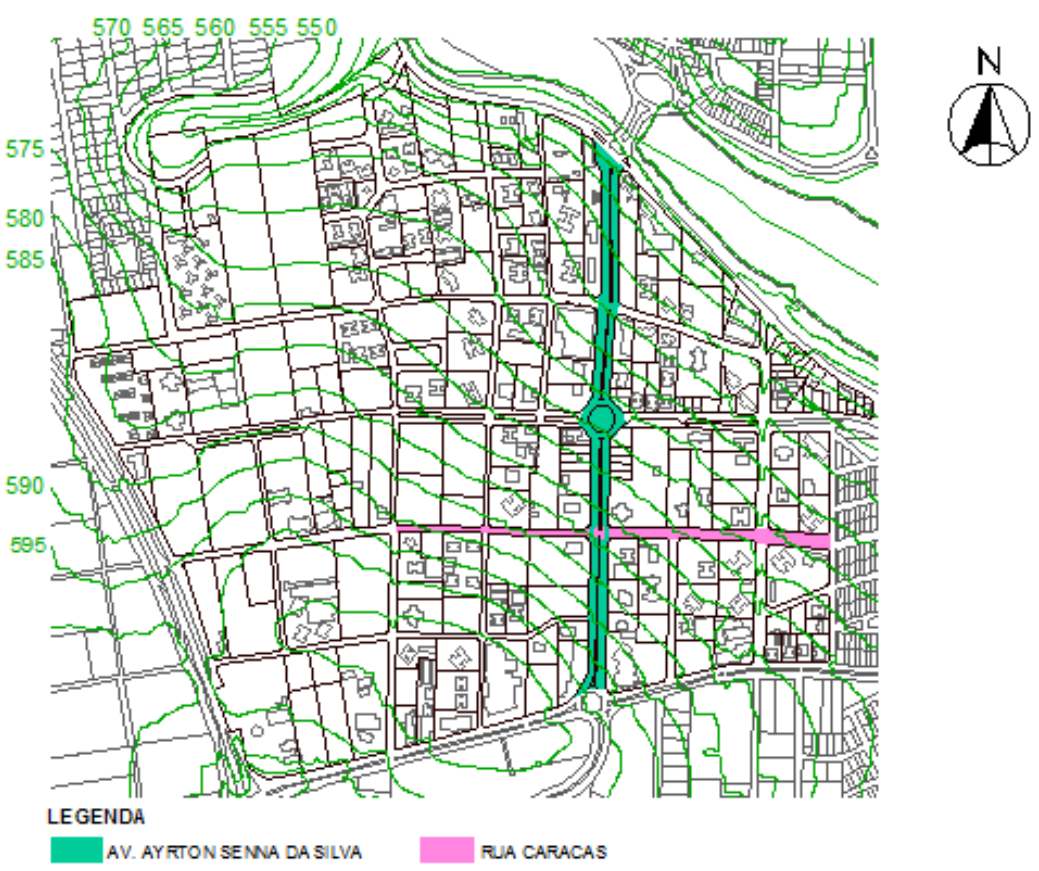

Fonte: Mauá (2015).

As implantações dos edifícios não consideram a circulação pedestre e a possibilidade de enxergar outras pessoas e atividades é limitada. Cabe lembrar que as pessoas não devem ser subjugadas pela circulação automotora. As ruas devem ser dimensionadas em proporção à quantidade de usuários potenciais, para que pedestres possam movimentar-se em espaços íntimos e bem definidos (GEHL, 2011).

\section{Dimensão de análise: usuários}

Aqui as qualidades recomendadas referem-se ao movimento e à densidade de pessoas nas ruas. $\mathrm{O}$ estudo de caso está inserido em uma região que apresenta números crescentes de densidade habitacional (IBGE, 2010; JORNAL DE LONDRINA, 2013), mas a variedade de usos é escassa, fator que contribui para o esvaziamento do espaço público.

A partir do total de apartamentos dos edifícios inseridos nesse segmento da Rua Caracas foi realizado um cálculo estimativo do total de residentes da área. As 400 unidades habitacionais existentes foram multiplicadas pelo índice de residentes de domicílio da área - 3,10 - o que resultou em uma média de 1.240 habitantes nos cinco edifícios analisados (IBGE, 2010). A Figura 18 demonstra o total de pedestres observados nos horários de maior movimento.

Considerando a média de 1.240 moradores, as contagens de pedestres (Figura 19) demonstram um baixo fluxo de pessoas na rua. No sábado e domingo uma porcentagem de $35 \%$ e $33,65 \%$ de moradores foi observada, respectivamente. Um maior movimento é constatado durante a semana, $57,21 \%$, fato que evidencia ser o espaço da rua prioritariamente utilizado pela população flutuante. O sucesso de espaços públicos é caracterizado pela presença de pessoas e deve-se dar prioridade de movimentos na seguinte ordem: a pé, bicicleta, transporte público e carro (CARMONA; HEATH; TIESDELL, 2010). Conforme supracitado, o tráfego veicular da Gleba Palhano é intenso e o movimento de pessoas nas ruas é baixo. Com base nos dados de contagem e de observação da Rua Caracas (Figura 20), é possível traçar um perfil dos usuários da área, com a predominância da presença de adultos e, ainda mais, de mulheres.

Não há diversidade de usos e igualdade de oportunidades, aspectos que auxiliariam na garantia de variedade de usuários. Constata-se uma clara distinção entre os moradores e os prestadores de serviços do local. Tal fenômeno é observado no primeiro horário de maior movimento, compreendido entre $7 \mathrm{~h} 30 \mathrm{~min}$ e $10 \mathrm{~h} 30 \mathrm{~min}$. Com exceção do domingo, o fluxo proeminente de mulheres adultas é de $74 \%$ e deve-se à chegada de funcionárias domésticas rumo ao trabalho. Salienta-se também o fluxo de homens adultos uniformizados, trabalhadores da área de construção civil. 
Figura 18 - Total de pedestres

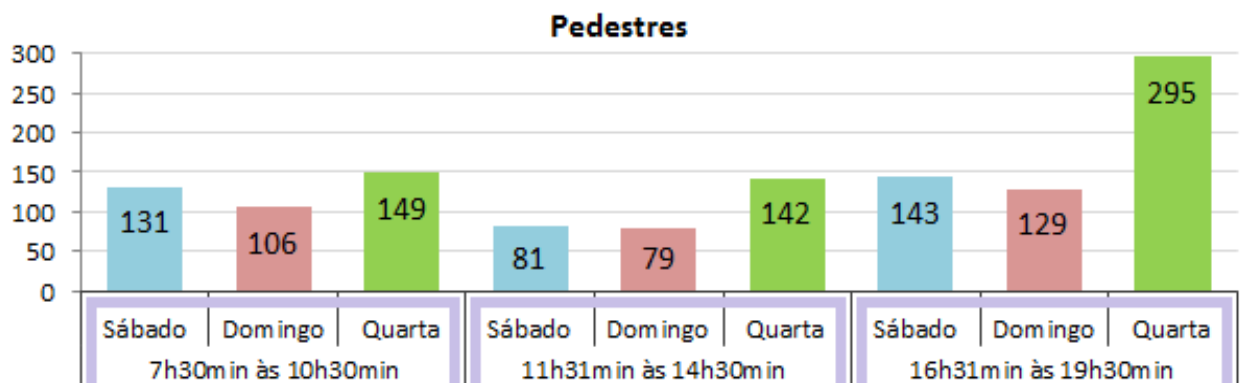

Fonte: Mauá (2015).

Figura 19 - Pedestres por hora

Fonte: Mauá (2015).

\begin{tabular}{|l|c|c|c|}
\hline \multicolumn{4}{|c|}{ Relação pedestres / hora } \\
\hline & $\mathbf{7 : 3 0 h}$ às 10:30h & 11:31h às 14:30h & 16:31h às 19:30h \\
\hline Sábado & 43,67 & 27 & 65 \\
\hline Domingo & 35,33 & 26,33 & 66,33 \\
\hline Quarta & 49,67 & 47,33 & 122 \\
\hline
\end{tabular}

Figura 20 - Perfis de usuários

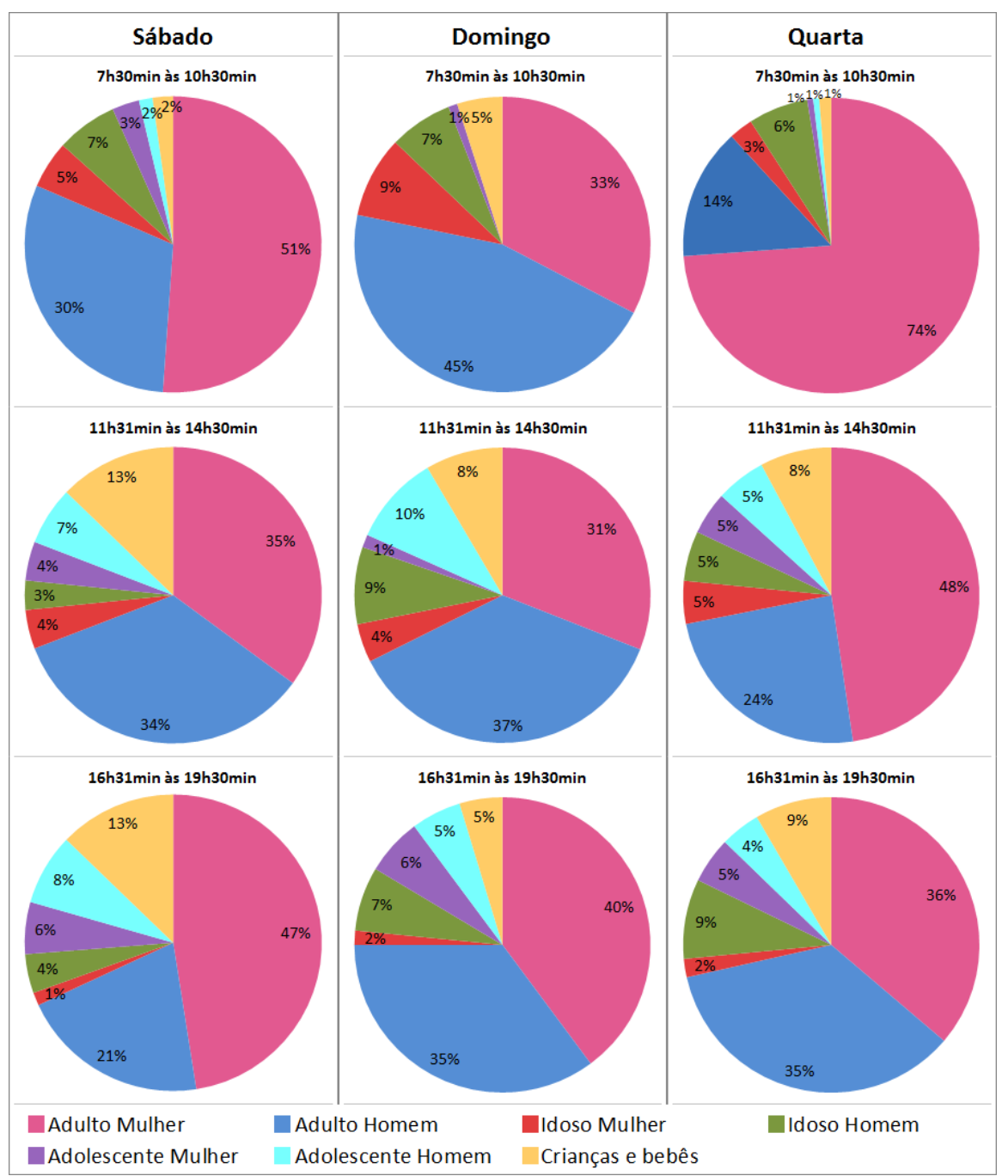

Fonte: Mauá (2015).

86 Mauá, L. B. C.; Guadanhim, S. J.; Kanashiro, M. 
A categorização de atividades realizada por Gehl (2011) aponta três modos de atividades ao ar livre: as necessárias; as opcionais e as sociais. As primeiras envolvem situações de locomoção ao trabalho, escola, espera pelo transporte público, entre outras. As segundas ocorrem somente quando as condições externas são favoráveis, como atividades recreativas e de repouso. Já as atividades sociais acontecem como consequência do movimento e da permanência das pessoas nos mesmos espaços.
Com a leitura das Figuras 21, 22 e 23 verifica-se que a rua é utilizada para passagem e abriga maior fluxo de atividades necessárias e não de atividades opcionais de recreação ou bem-estar. Essas observações confirmam a validade das preocupações de Gehl (2011), quando o autor afirma que são pessoas que devem ser agrupadas, e não construções.

A presença de crianças e idosos constitui-se como qualidade recomendada (JACOBS, 2000; GEHL, 2011; RAPOPORT, 1978; APPLEYARD, 1981; CARMONA; HEATH; TIESDELL, 2010).

Figura 21 - Atividades necessárias e opcionais - sábado

SÁBADO - atividades necessárias e opcionais

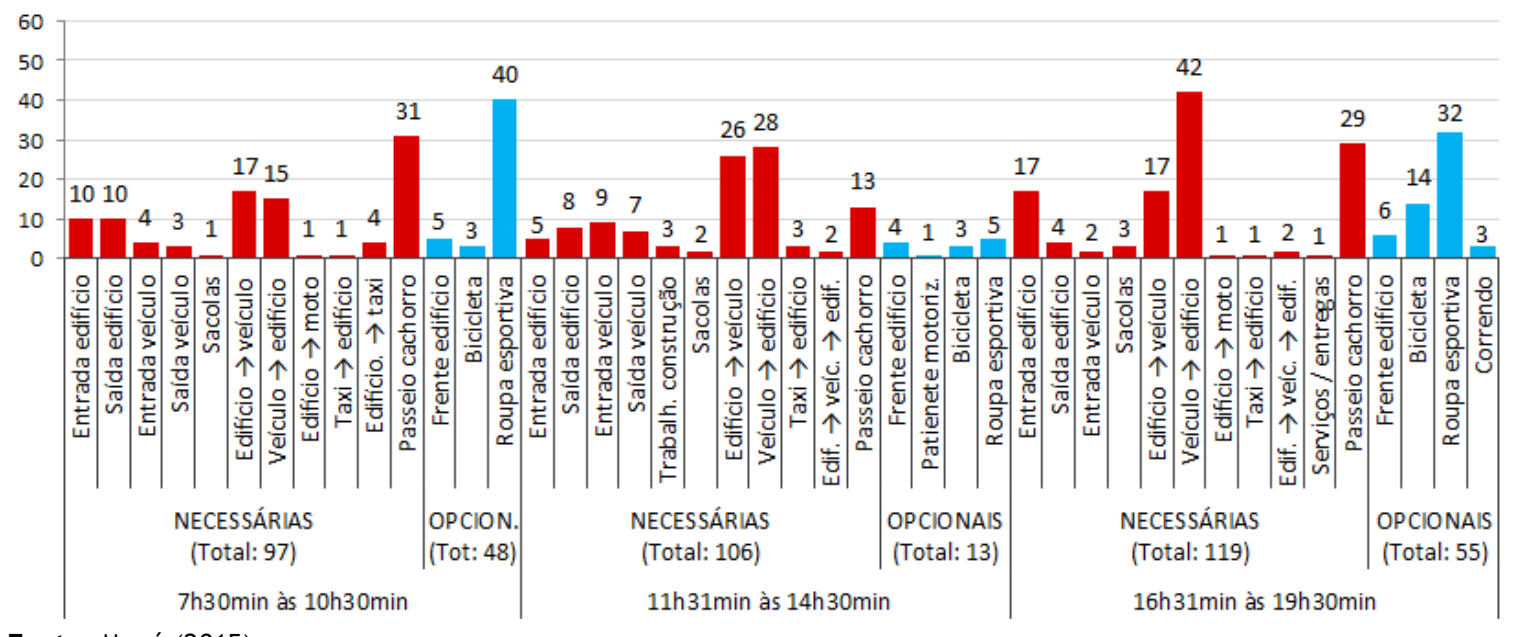

Fonte: Mauá (2015).

Figura 22 - Atividades necessárias e opcionais - domingo

DOMINGO - atividades necessárias e opcionais

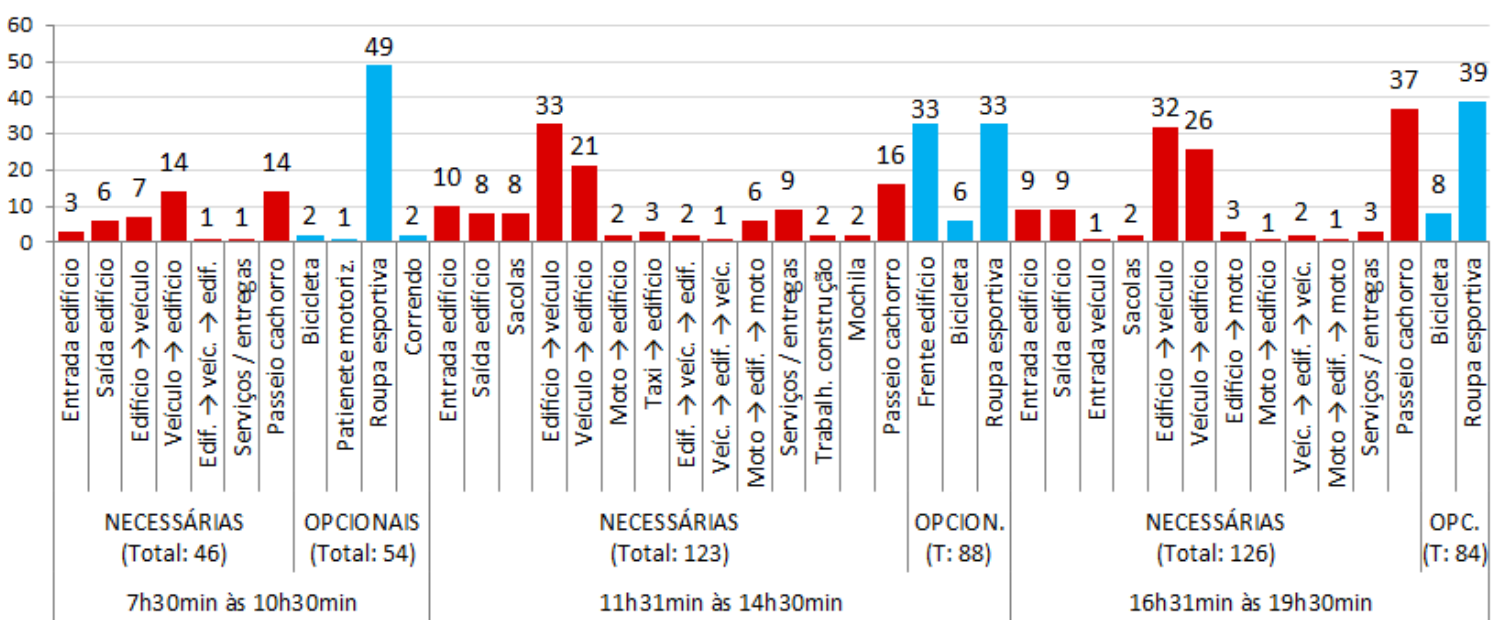

Fonte: Mauá (2015). 
QUARTA - atividades necessárias e opcionais

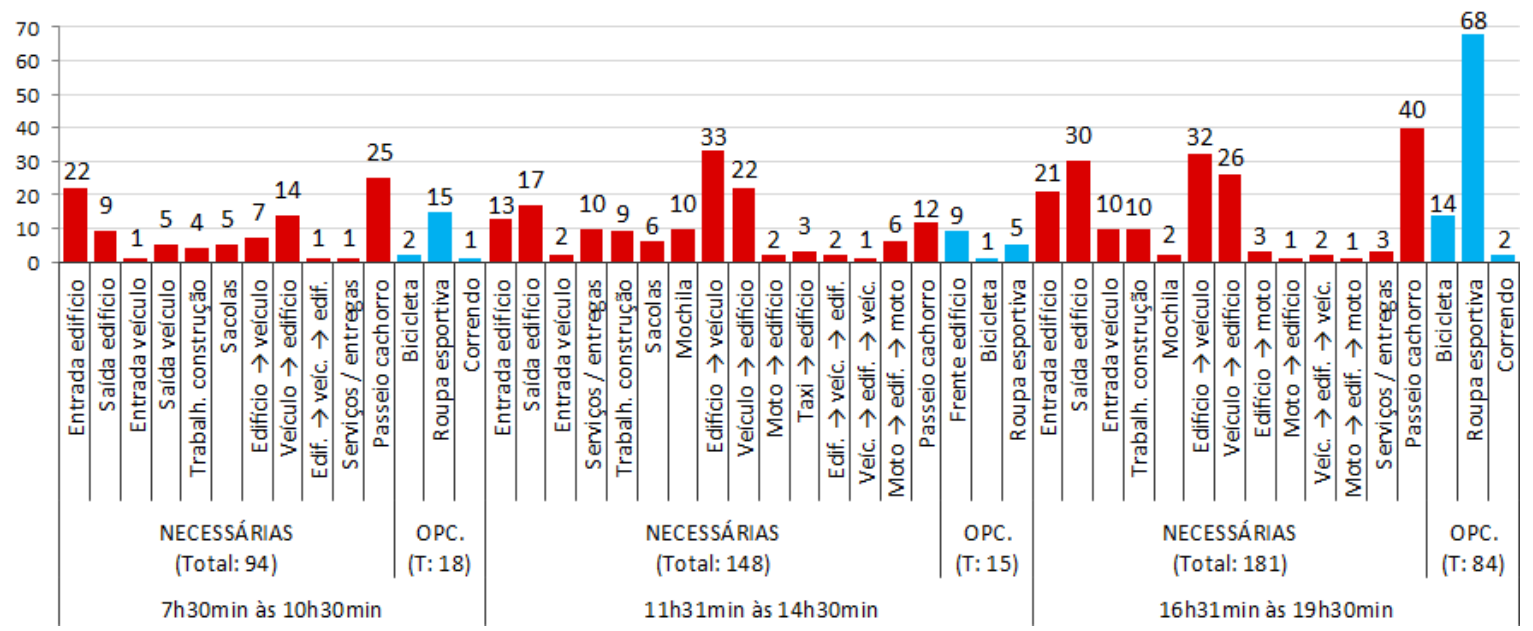

Fonte: Mauá (2015).

Assim como os gráficos de variedade dos usuários, as Figuras 24 e 25 demonstram que o movimento de idosos e crianças na rua é baixo. Alguns idosos caminham com roupas esportivas. Mas os números, incluindo crianças, devem-se prioritariamente às passagens e atividades obrigatórias. Proporcionar condições para atividades de adultos e idosos, conforme aconselha Jacobs (2000) e Gehl (2011), não é a realidade do local. São poucos idosos nas ruas e há ausência de condições para atividades infantis.

As ruas necessitam de movimento em diferentes horários. Aqui se apresenta a quantidade de pedestres a cada hora (Figura 26). Além disso, a análise de fluxo veicular em horários distintos (Figura 27) revela as diferenças de movimento de fluxos nos diferentes dias e torna possível uma comparação entre os números de deslocamentos de pedestres e automóveis.

O movimento de pedestres é escasso e notam-se alguns horários nos quais as ruas permanecem ainda mais vazias. A diversidade comercial é baixa, bem como a variação de usos. O maior fluxo de pedestres ocorre aproximadamente até às $18 \mathrm{~h} 30 \mathrm{~min}$, quando o movimento passa a cair e, a partir das 19h30min, a rua torna-se vazia e escura.

O trânsito na Gleba Palhano vem se mostrando um problema aos moradores da região que reivindicam providências para melhoria do trânsito e redução de acidentes, que ocorrem com frequência (JORNAL DE LONDRINA, 2013, 2014; JORNAL DA GLEBA, 2015). Ruas com trânsito intenso ocasionam interações sociais escassas entre moradores (APPLEYARD, 1981). A dimensão de análise de usuários demonstra uma área que, por não comportar diversidade e atividades, resultou em ruas vazias, ausência de interações sociais e predomínio da circulação de veículos.

\section{Dimensão de análise: visuais}

Sociedade e cultura interferem nas escolhas dos indivíduos e o design urbano deve prover oportunidades e não negar possíveis escolhas, garantindo o máximo de versatilidade dentro dos limites de custos (BENTLEY et al., 1999; CARMONA; HEATH; TIESDELL, 2010).

Observa-se que a variedade de tipo de edifícios também é fator ausente e existe certa padronização, mesmo que sejam componentes de diferentes condomínios. Não apenas em termos estéticos, os usos das edificações apresentam-se, principalmente (e na Rua Caracas exclusivamente), por uso residencial e poucas torres comerciais. Por ser uma área recentemente ocupada, também não existe variação significativa de épocas das construções. Rapoport (1978) discrimina as fachadas como fatores que devem ser planejados e que reproduzem complexidade urbana. No campo visual, as pessoas preferem configurações complexas, que abrangem cores, texturas e formas.

A superfície do edifício Sun Flowers possui certa irregularidade, alternada com elementos vazados e alguns taludes gramados (Figura 28 e 29). Ademais, as fachadas são retilíneas, ora alternando acabamentos e algumas grades metálicas, mas sem representar nenhum tipo de suporte ao espaço público, contrastes visuais ou variedade de elementos. 
Figura 24 - Idosos e crianças

Fonte: Mauá (2015).

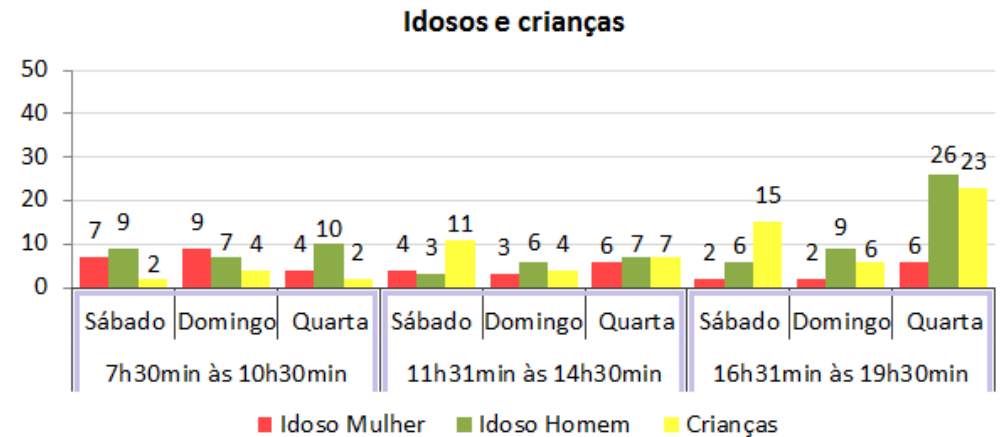

Figura 25 - Total de idosos e crianças

Total - Idosos e crianças

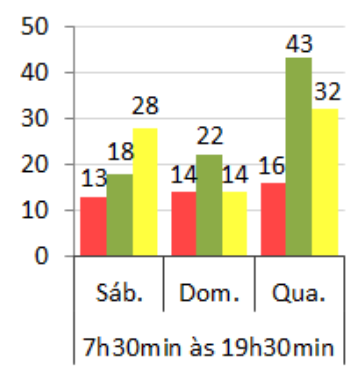

Fonte: Mauá (2015).

n Id. Mulh. a Id. Hom. Crian

Figura 26 - Quantidade de pedestres

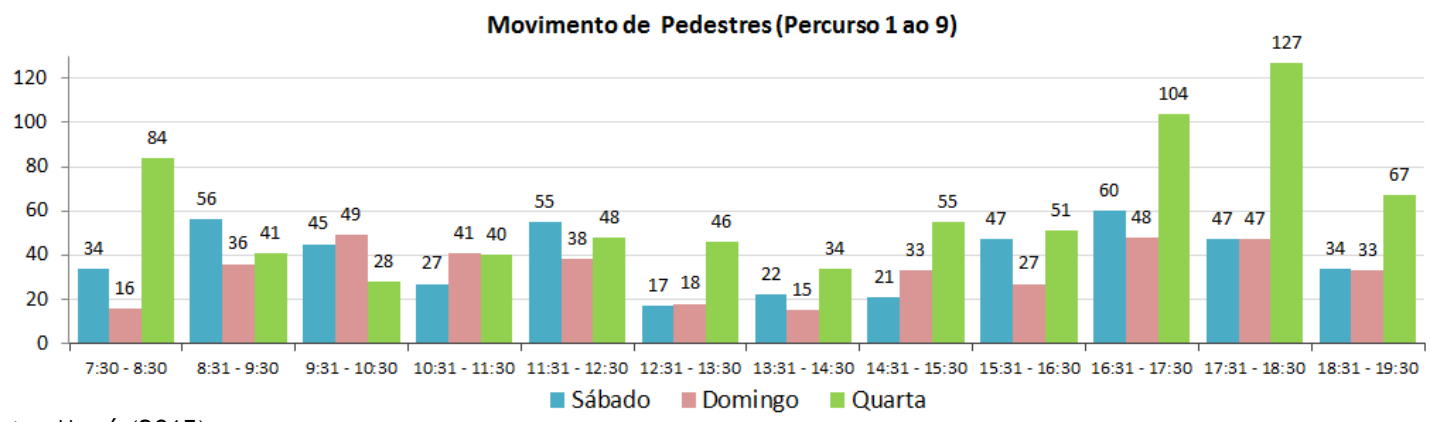

Fonte: Mauá (2015).

Figura 27 - Quantidade de veículos

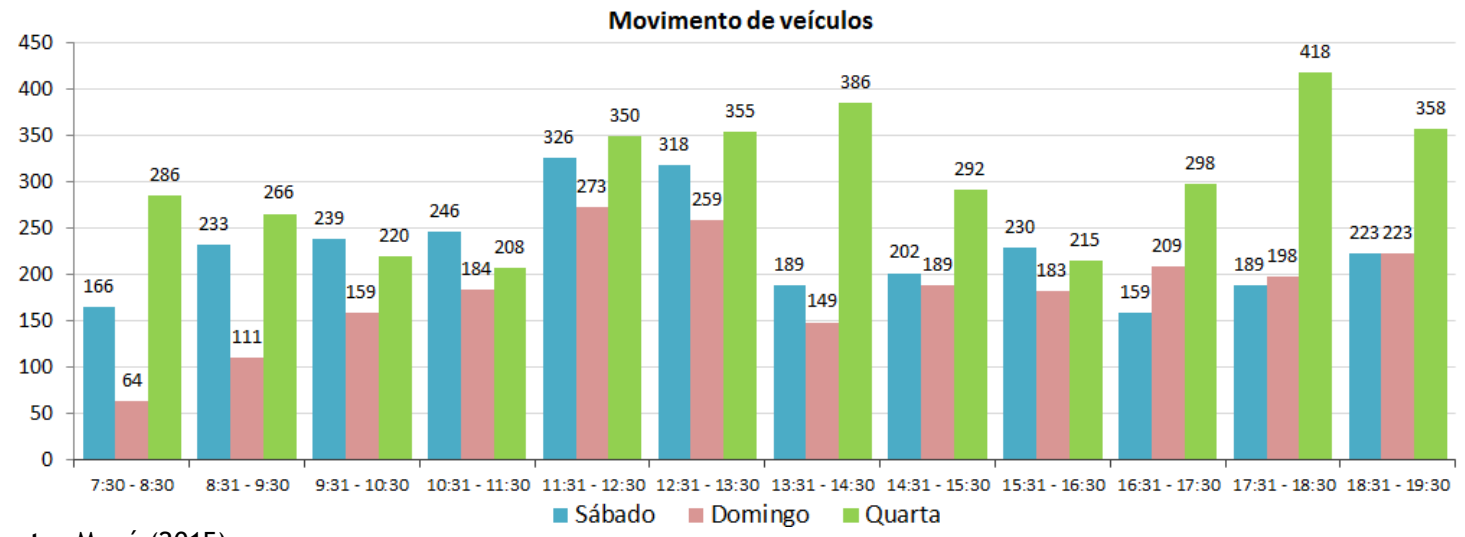

Fonte: Mauá (2015). 
Figura 28 - Ed. Sun Flowers

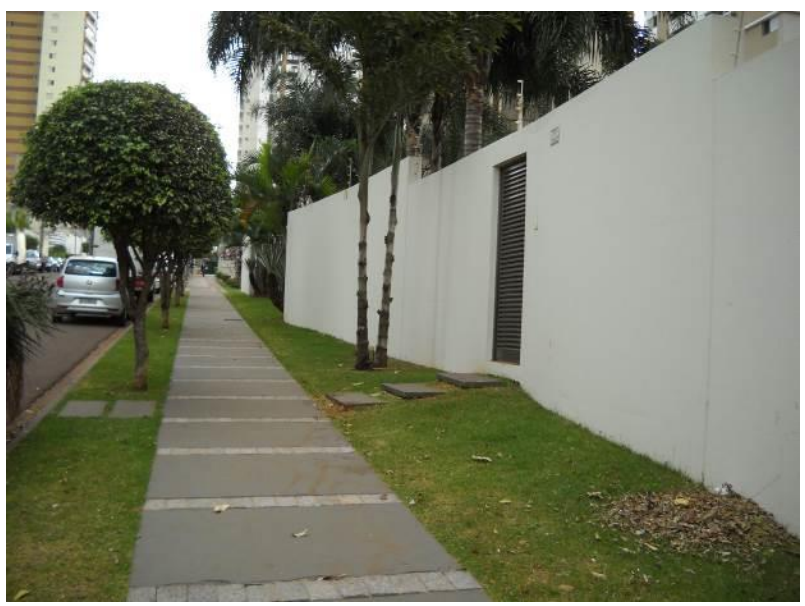

Fonte: Mauá (2015).

Figura 29 - Ed. Sun Flowers

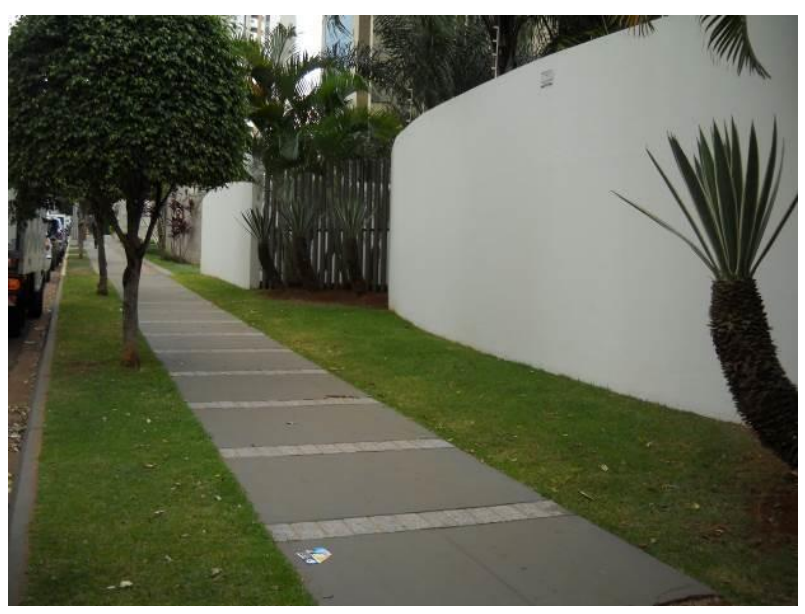

Fonte: Mauá (2015).

Figura 30 - Ed. Gaudí e Ed. L'Essence

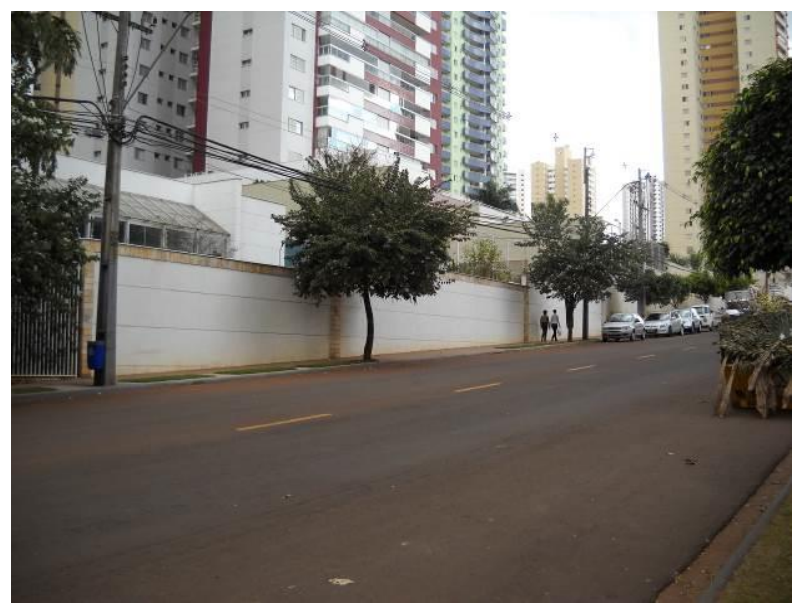

Fonte: Mauá (2015).

90 Mauá, L. B. C.; Guadanhim, S. J.; Kanashiro, M. 
Figura 31 - Ed. Gaudí

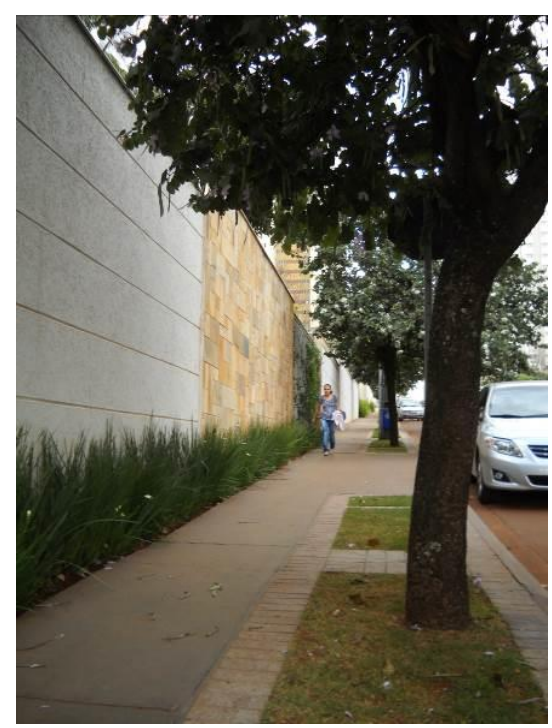

Fonte: Mauá (2015).

Figura 32 - Corte da Rua Caracas

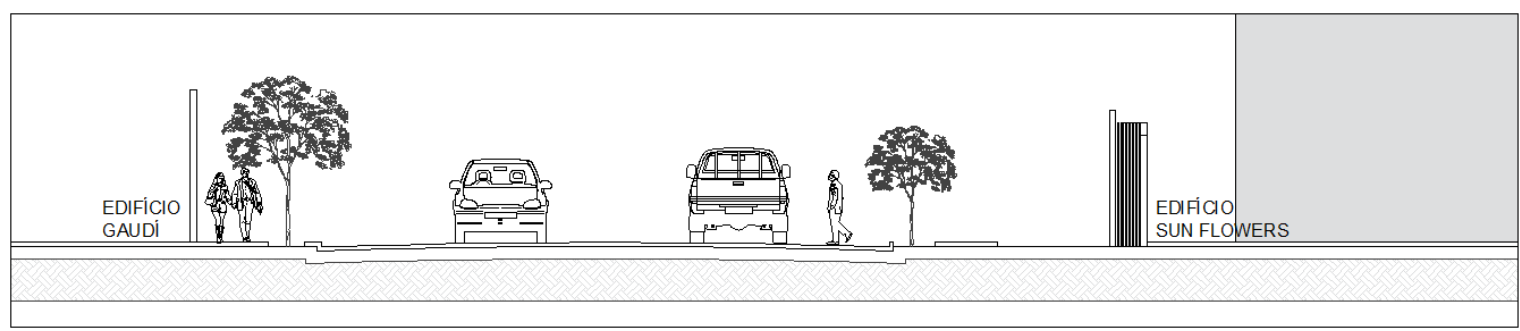

Fonte: Mauá (2015).

Figura 33 - Superfícies limites privados - Rua Caracas

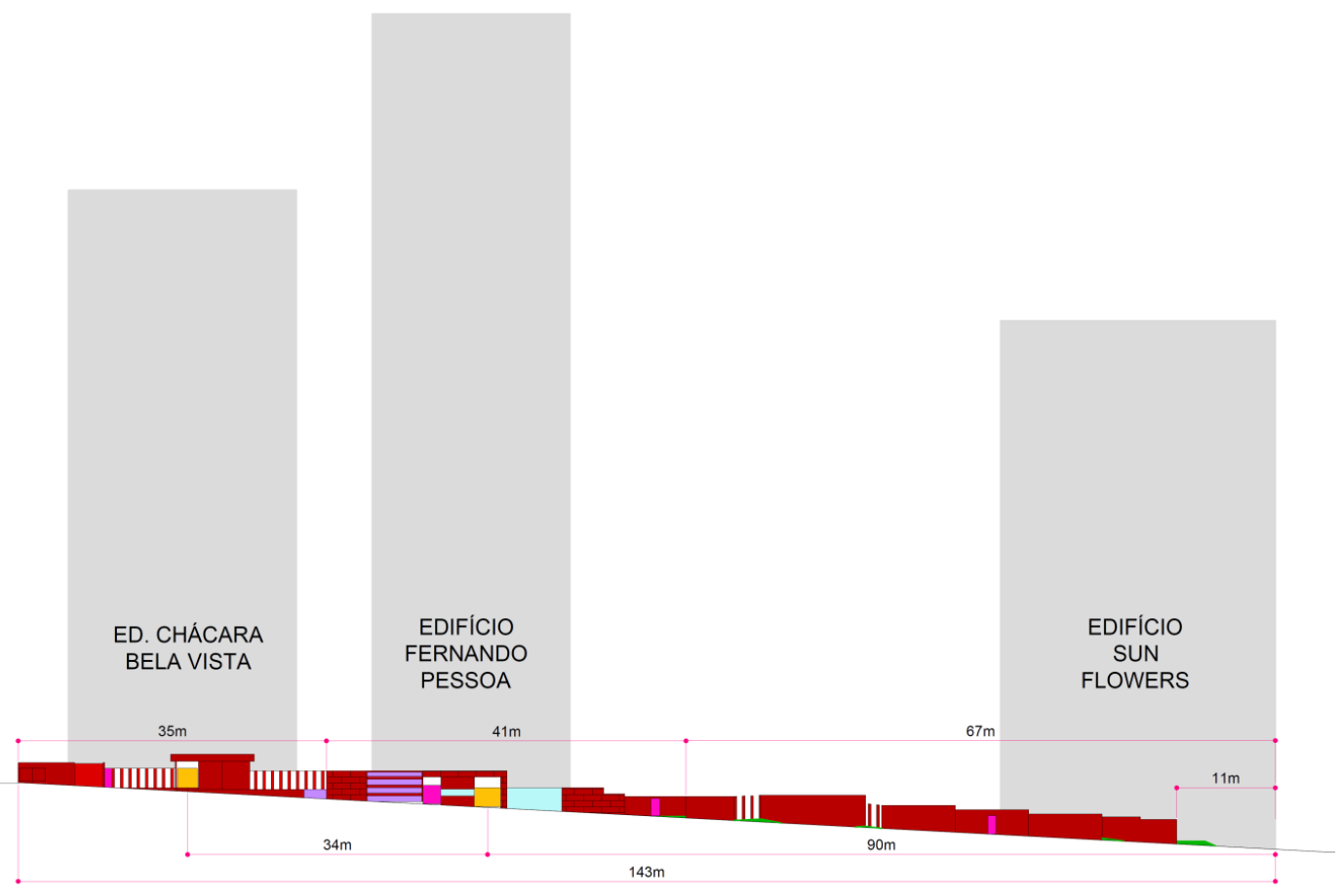

Fonte: Mauá (2015). 
Os espaços públicos e privados mantêm limites bem definidos, mas sem escalas de diferenciação além dos muros e sem permeabilidade (Figuras 30 e 31). A proporção entre altura edificada e largura da seção da rua é de 1:6 (Figura 32) e encontra-se com nível superior ao que é defendido por Carmona, Heath e Tiesdell (2010): espaços com proporções entre 1:2 e 1:2,5 garantem um bom senso de fechamento, aceitando-se como mínimo a proporção 1:1. Salienta-se que a proporção encontrada é resultado dos limites privados - os muros dos edifícios - em relação com a rua. Em regiões verticalizadas, os afastamentos entre as torres são necessários para haver privacidade e conforto ambiental, evitando-se sombreamentos excessivos.

Verifica-se a ausência de lojas, sinalizações e número suficiente de acessos (Figuras 33 e 34), elementos considerados bons atributos para superfícies de edifícios em relação com as ruas (WHYTE, 1980; GEHL, 2011). Vias com menores índices de tráfego podem ser apoiadas por elementos construtivos de suporte a locais de encontro e lazer (APPLEYARD, 1981).
As superfícies não comportam locais de permanência. O edifício Chácara Bela Vista possui entrada recuada com jardins (Figura 33). No entanto, o local que poderia ser utilizado pelas pessoas não possui nenhum tipo de mobiliário e parte é destinada ao estacionamento de veículos de visitantes. Tais características, somadas à falta de varandas e jardins frontais, conformam espaços rígidos, com permeabilidade obstruída (BENTLEY et al., 1999). Desse modo, pode-se constatar que não foi dada a atenção devida às partes das fachadas em relação à rota de pedestres, pois os acessos mantêm-se muito distantes entre si. As esquinas dos condomínios residenciais são, em sua maioria, muradas, como a esquina da Rua Caracas com a Rua Antonio Pisicchio, onde se localiza o edifício L'Essence (Figuras 35 e 36).

Quanto às calçadas, estas possuem largura de três metros, são arborizadas, algumas partes contêm piso tátil, canteiros com vegetação, lixeiras, câmeras dos edifícios locadas nos muros e postes de luz (Figura 37). A arborização baixa contribui para que a calçada fique escura à noite.

Figura 34 - Superfícies limites privados - Rua Caracas

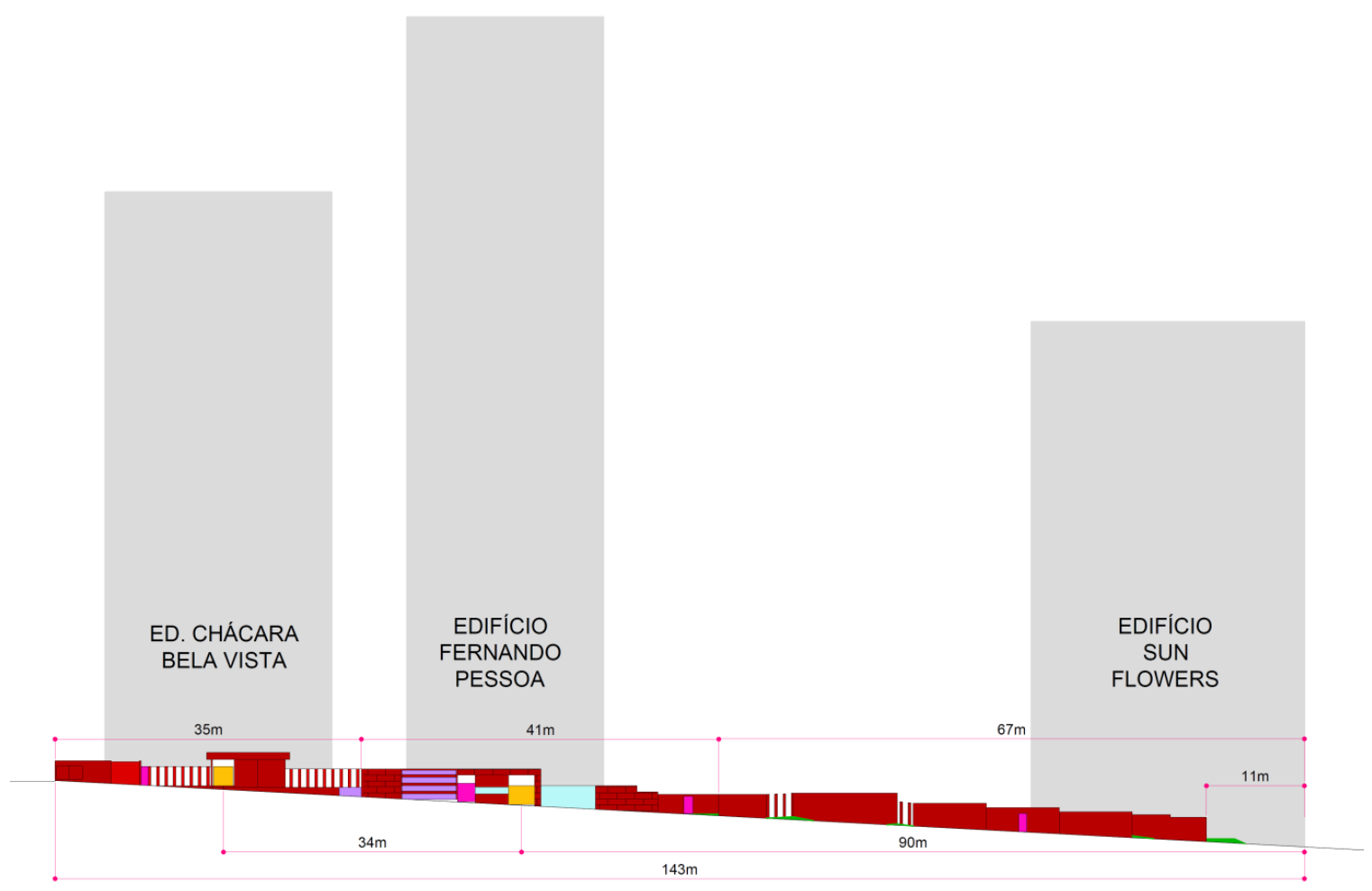

Fonte: Mauá (2015). 
Figura 35 - Esquina R. Caracas com R. Antonio Pisicchio - Ed. L’Essence

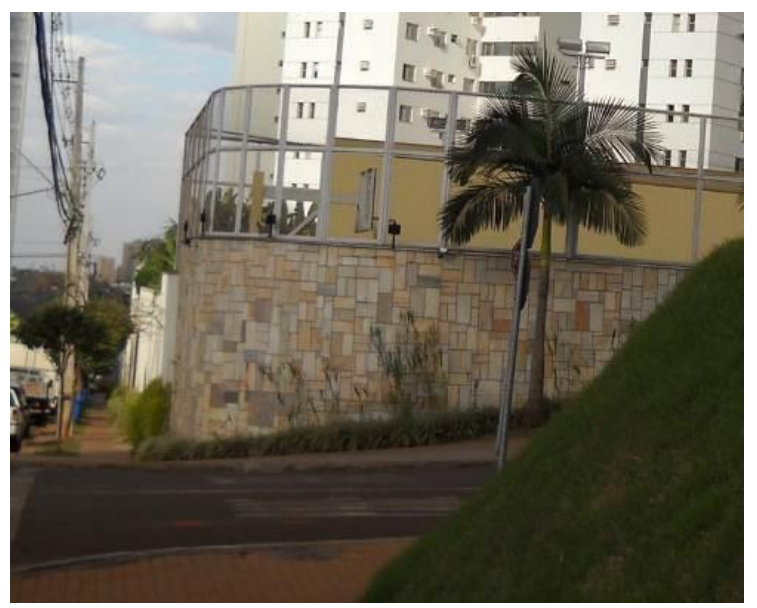

Fonte: Mauá (2015).

Figura 36 - Esquina R. Caracas com R. Antonio Pisicchio - Ed. Paranoá

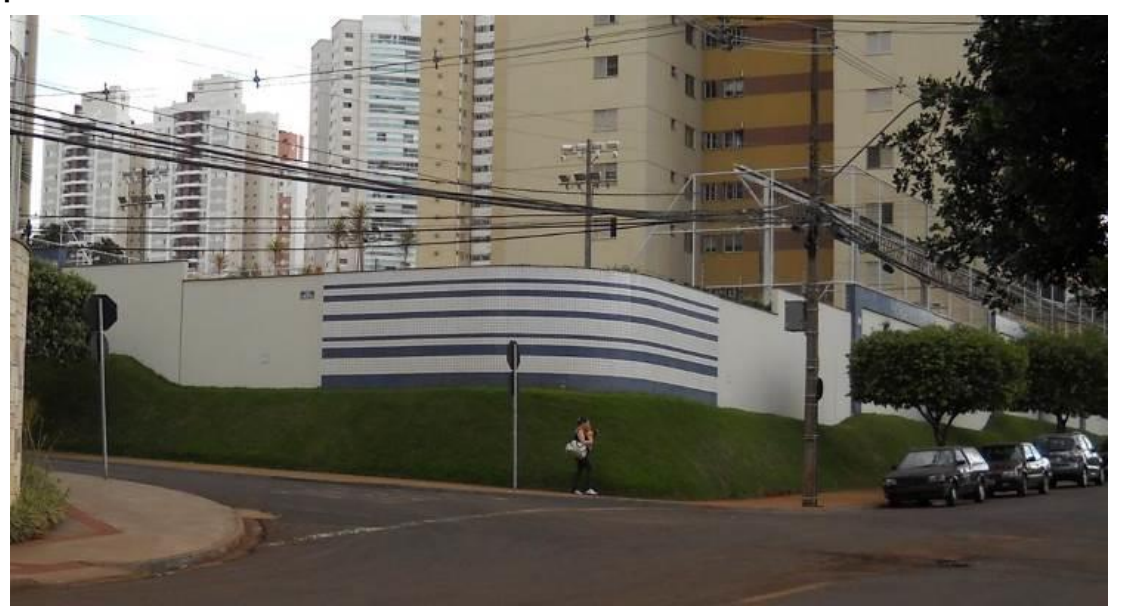

Fonte: Mauá (2015).

Figura 37 - 1Segmento planta baixa Rua Caracas - pista e calçadas

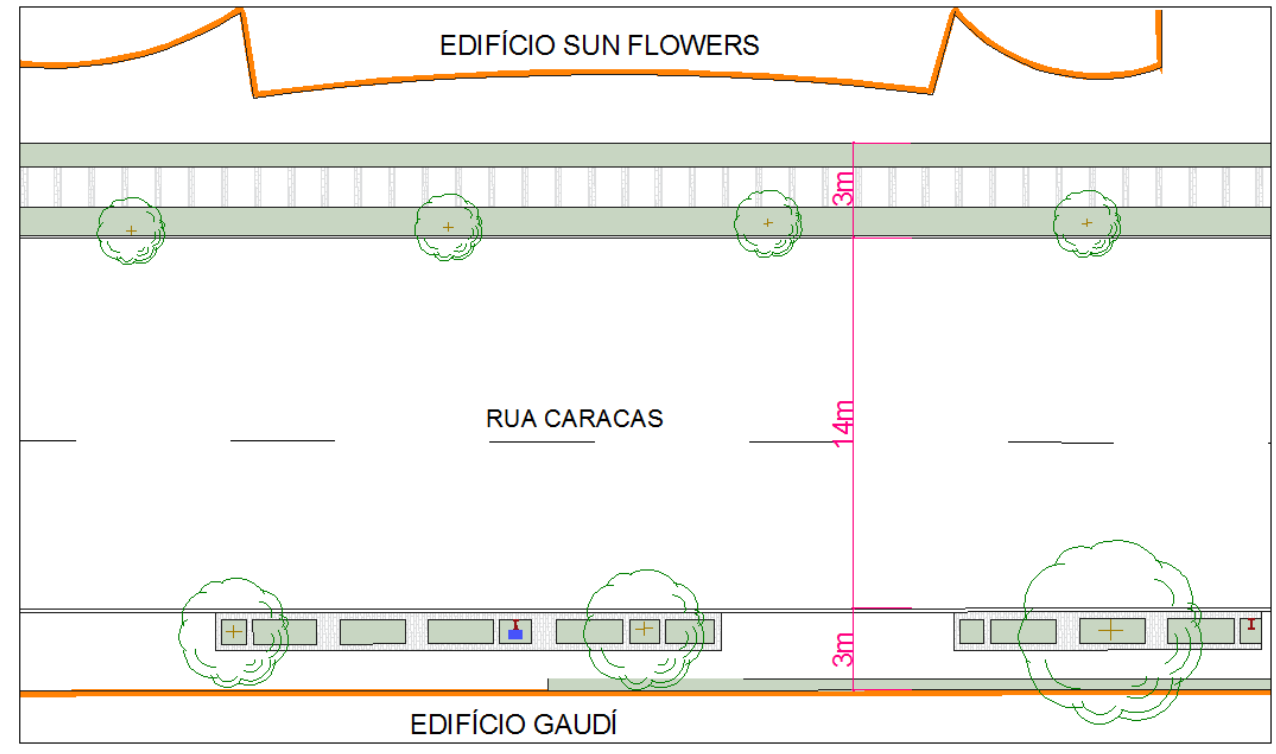

Fonte: Mauá (2015). 
Jacobs (2000) enxerga de modo negativo áreas com vigilância forçada. Segundo a autora, isso colabora com a segregação e a discriminação espacial na conformação de ruas vazias. Analisando o perfil da área, comprova-se monotonia predominante, também apoiada pelas dimensões dos grandes lotes, pela falta de destinação de diferentes usos e ausência de pequenas praças e espaços livres distribuídos pelo local.

Atenção à limpeza e manutenção pode gerar atratividade nas ruas (APPLEYARD, 1981). Nesse aspecto, foi observada a conservação das calçadas por parte de funcionários dos edifícios adjacentes. Porém, isso não estimula a apropriação das ruas.

Por meio da análise das características do estudo de caso, verifica-se com clareza que a Rua Caracas na Gleba Palhano não possui as qualidades recomendadas propostas teoricamente, ainda que as críticas que evidenciam a importância dessas qualidades nas ruas existam e não sejam recentes.

\section{Considerações finais}

Inicialmente, pode-se confirmar a persistência da maior parte dos problemas tratados pela literatura, composta de estudos e observações em conjunturas e espaços temporais divergentes do apresentado. Enquanto os autores que investigam a qualidade por meio de avaliações dos espaços públicos indicam características que permeiam o convívio, os encontros, os usos e as facilidades aos cidadãos, a produção da cidade sob o recorte do modelo de verticalização atual desconsidera tais aspectos.

O espaço público não é tomado como ambiente de convívio, nem de movimento de pedestres, apenas de veículos. Em termos de uso, enquanto as ruas residenciais se demonstram fracassadas, as vias de passagem de tráfego se apresentam cada vez mais aglomeradas e sem zonas para novos estacionamentos.

O caso estudado, a Gleba Palhano, é uma área valorizada na cidade de Londrina, com alto custo de terra, mas, como mostram os resultados obtidos, não conforma ruas com qualidade urbana. $\mathrm{O}$ esvaziamento das ruas decorre do planejamento que admite a monofuncionalidade e a verticalização, sustentando a segregação espacial e social, por não contemplar o entorno e o espaço urbano dos lugares nos quais estão inseridos.

Envoltos em questões multidisciplinares, a arquitetura e o urbanismo visam a geração de espaços que deveriam ser planejados de acordo com a satisfação e as necessidades das pessoas. A realidade aponta um objetivo diverso, em que o mercado e o lucro tornam-se componentes preponderantes. $\mathrm{O}$ contexto protagonizado por empreendimentos imobiliários, comercializados por construtoras e incorporadoras, apresenta $\mathrm{o}$ modo de operação dessas empresas que segue as lógicas capitalistas de lucro e sua produção é fundamentada em vendas. Essa realidade envolve, entre outras questões, demandas instituídas por marketing e especificações legislativas, que implicam também o papel do poder municipal nessa prática.

Tratando-se de tais mecanismos, Harvey aborda a sobreposição das prerrogativas da propriedade privada e das taxas de lucro a qualquer noção de direito humano. $\mathrm{O}$ autor explora, sobretudo, o direito à cidade. Os esforços de ressignificação dos ideais sociais para "[...] construção de um mundo melhor [...]" ainda não "[...] desafiam a hegemonia liberal e a lógica de mercado neoliberal ou o modo dominante de legalidade e ação estatal [...]" (HARVEY, 2012, p. 73).

Aqui a avaliação da Rua Caracas demonstra que o modelo verticalizado amplamente difundido é danoso e acaba por prejudicar parcelas da sociedade. Podem-se apontar, principalmente, os prestadores de serviço da área. A necessidade de caminhar dentro do perímetro em questão leva a deparar-se com ambientes que não são agradáveis, com muros extensos, monotonia, esvaziamento, pistas largas e, em alguns casos, dificuldade para atravessá-las.

Confirmam-se afirmativas quanto às aplicações de uso e ocupação do solo, que ocorrem de forma arbitrária. A concorrência pelo domínio das rendas imobiliárias compõe um conflito silencioso, em que o uso e as ocupações do solo não deveriam servir como ferramenta de segregação e ampliação do custo da terra, mas sim para aumentar o direito à cidade (MARICATO, 2011).

Aponta-se a indispensabilidade de modos alternativos de verticalização, uma vez que tal fenômeno pode contribuir positivamente aos espaços. A ocupação vertical não pressupõe necessariamente a ausência da diversidade de indivíduos, de usos e atividades, do mesmo modo que sua inserção pode indicar mais preocupação com seu entorno e, consequentemente, os usuários desses espaços.

Harvey (2012, p. 86) aponta a necessidade de “[...] descobrir uma oposição coerente a estes desdobramentos no século XXI [...]" em um cenário que favorece o capital corporativo e as classes abastadas, ressalta-se a necessidade de consolidação de práticas democráticas sobre a estruturação urbana. 
Desse modo, cabe identificar e analisar os problemas, a fim de combatê-los em favor do direito à cidade. Este estudo demonstra diversos aspectos de impacto dos usos dos locais em área de ocupação vertical, levantando caminhos contrários ao bem-estar das pessoas. Edifícios, ruas, praças e, por fim, as cidades são o abrigo e o envoltório constante dos indivíduos. Faz-se urgente discutir os atuais mecanismos de controle da execução dos lugares de forma a inverter o objetivo da prática atual, que se transmuta do bem-estar do individuo a seu prejuízo.

O método aqui empregado possibilitou a demonstração de diversos fatores e, ainda, os possíveis desdobramentos de cada um deles. A organização das qualidades recomendadas e suas respectivas dimensões (usos, deslocamentos, usuários e visuais) confirmam a vasta problemática que o modelo de verticalização atual abrange e os diversos aspectos de indispensável aprofundamento para processos urbanos voltados às pessoas, e ao verdadeiro direito à cidade, direito este pautado na coletividade.

\section{Referências}

ALAS, P. O Fenômeno dos Supercondomínios: verticalização na metrópole paulistana no início do século XXI. Dissertação (Mestrado em Concentração: Paisagem e Ambiente) - Faculdade de Arquitetura e Urbanismo, Universidade de São Paulo, São Paulo, 2013.

ALVES, J. X. S. Cidade de Muros. JC: Jornal da Cidade de Bauru, Opinião, p. 2, 25 fev. 2013. Disponível em:

<http://www.jcnet.com.br/editorias_noticias.php?c odigo=227569> . Acesso em: 24 fev. 2014.

APPLEYARD, D. Livable Streets. Berkeley, University of California Press, 1981.

BENTLEY, I. et al. Hacia un diseño urbano y arquitectónico más humano: manual prático. Barcelona: Gustavo Gili, 1999. Entornos Vitales.

CALDEIRA, T. P. Cidade de Muros: crime, segregação e cidadania em São Paulo. São Paulo: Editora 34; Edusp, 2000.

CARMONA, M.; HEATH, T.; O. C. T.; TIESDELL, S. Public Places Urban Spaces: the dimension of urban design. $2^{\text {nd }}$. ed. Oxford: Elsevier, 2010.

CORRÊA, R. L. O espaço Urbano. São Paulo: Ática, 1999.
CUSTÓDIO, R. Às Vezes, Pedestres Têm de Esperar Alguns Minutos Para Atravessar na Faixa na Avenida Ayrton Senna. Jornal de Londrina. Estudo Busca Melhorar Tráfego na Gleba Palhano. Londrina, jul. 2014.

GEHL, J. Life Between Buildings Using Public Space. Washington: Island Press, 2011.

HARVEY, D. O Direito à Cidade. Lutas Sociais, São Paulo, v. 29, p-73-89, jul./dez. 2012.

HOLANDA, F.; KOHLSDORF, M. E.; KOHLSDORF, G. Brasília: da Carta de Atenas à Cidade de Muros. In: Seminário DOCOMOMO Brasil - Caderno de Resumos. São Carlos: Depto. de Arquitetura e Urbanismo, Escola de Engenharia de São Carlos, Universidade de São Paulo, 2003.

INSTITUTO BRASILEIRO DE GEOGRAFIA E ESTATÍSTICA. Censo do Brasil 2010. 2010.

Disponível em:

<http://www.censo2010.ibge.gov.br/sinopseporset ores/>. Acesso em: 10 jan. 2015.

INSTITUTO DE PESQUISA E PLANEJAMENTO URBANO DE LONDRINA. Mapas temáticos: Perímetro Urbano. Disponível em: <http://www.londrina.pr.gov.br>. Acesso em: 02 ago. 2014.

JACOBS, J. Morte e Vida de Grandes Cidades. São Paulo: Martins Fontes, 2000.

JORNAL DA GLEBA. Crescimento

Desordenado Pode Comprometer a Gleba

Palhano. Londrina, p. 4, jun. 2013.

JORNAL DA GLEBA. Ideias Para o Trânsito. Londrina, p. 4, jan. 2015.

JORNAL DE LONDRINA. Gleba Palhano Fica Sem Espaço Para os Equipamentos Públicos. Londrina, jul. 2013.

JORNAL DE LONDRINA. Estudo Busca Melhorar Tráfego na Gleba Palhano. Londrina, jul. 2014. Disponível em:

<http://www.jornaldelondrina.com.br/londrina/con teudo.phtml?tl=1\&id=1486108\&tit=Estudo-buscamelhorar-trafego-na-Gleba-Palhano>. Acesso em: 30 jul. 2014.

MARICATO, E. Brasil, Cidades: alternativas para a crise urbana. 4. ed. Rio de Janeiro: Vozes, 2011. 
MAUÁ, L. B. C.; GUADANHIM, S. J. A

Legislação Urbanística e a Paisagem das Ruas: uma análise dos parâmetros da lei na relação dos espaços privados e públicos. In: ENCONTRO NACIONAL DE ENSINO DE PAISAGISMO EM ESCOLAS DE ARQUITETURA E URBANISMO NO BRASIL, 12., Vitória, 2014. Anais... Vitória... 2014.

MAUÁ, L. B. C. Qualidade do Espaço Público Rua - em Áreas de Ocupação Vertical Recente: discussão baseada em estudo de caso. Londrina, 2015. Dissertação (Mestrado em Arquitetura e Urbanismo) - Departamento de Arquitetura e Urbanismo, Universidade Estadual de Londrina, Londrina, 2015.

MORAIS, L. S.; SILVA, P. C. M.; MEDEIROS, W. D. A. Análise do Processo de Verticalização na Área Urbana do Município de Mossoró-RN: aspectos jurídicos e ambientais. Revista Verde De Agroecologia e Desenvolvimento Sustentável, v. 2, n. 2, p. 171-182, 2007.

RAMIRES, J. C. de L. O Processo de Verticalização das Cidades Brasileiras. Boletim de Geografia, Maringá, v. 16, n. 1, p. 97-105, 1998.

RAPOPORT, A. La Importância y la Natureza de la Percepción Ambiental. In: ASPECTOS humanos de La forma urbana: hacia uma confrontación de las Ciencias Sociales com el diseño de la forma urbana. Barcelona: Gustavo Gili, 1978.
ROLNIK, R. Verticalização: para além do debate do sim ou não. Disponível em:

<https://raquelrolnik.wordpress.com/2014/03/27/v erticalizacao-para-alem-do-debate-do-sim-ounao/>. Acesso em: 28 mar. 2014.

\section{SILVA, A. L. Loteamentos Residenciais}

Exclusivos de Londrina: outras fronteiras imaginárias e invisíveis. Londrina, 2007.

Dissertação (Mestrado em Geografia Meio Ambiente e Desenvolvimento) - Faculdade de Geografia, Universidade Estadual de Londrina, Londrina, 2007.

SILVA, A. L. da; CARVALHO, M. S. de. Ecoville e Gleba Palhano: uma análise da produção do espaço urbano a partir dos edifícios de alto padrão. Vitruvius, mar. 2013. Disponível em: <http://www.vitruvius.com.br/revistas/read/arquite xtos/13.154/4685>.

TRAMONTANO, M. Apartamentos em São Paulo: brevíssimo exame de uma história controversa. Revista AU - Arquitetura e Urbanismo, p. 68-71, abr. 2006.

WHYTE, W. The Social Life of Small Urban Spaces. Washington: The Conservation Fundation, 1980.

YIN, R. K. Estudo de Caso, Planejamento e

Métodos. 2. ed. São Paulo: Bookman, 2001.

\footnotetext{
Lígia Beatriz Carreri Mauá

Departamento de Arquitetura e Urbanismo | Universidade Paulista | Av. Independência, 210, Éden | Sorocaba - SP - Brasil |
} CEP 18087-101 | Tel.: (15) 3412-1000 | E-mail: ligiamaua@hotmail.com

\section{Sidnei Junior Guadanhim}

Departamento de Arquitetura e Urbanismo, Centro de Tecnologia e Urbanismo | Universidade Estadual de Londrina | Rodovia Celso Garcia | Cid, PR 445, km 380, Campus Universitário | Caixa Postal 6001 | Londrina - PR - Brasil | CEP 86055-900 | Tel.: (43) 3371-4535 |

E-mail: sjg@uel.br

\section{Milena Kanashiro}

Departamento de Arquitetura e Urbanismo, Centro de Tecnologia e Urbanismo | Universidade Estadual de Londrina | E-mail: milena@uel.br

\section{Revista Ambiente Construído}

Associação Nacional de Tecnologia do Ambiente Construído

Av. Osvaldo Aranha, $99-3^{\circ}$ andar, Centro

Porto Alegre - RS - Brasil

CEP $90035-190$

Telefone: +55 (51) 3308-4084

Fax: +55 (51) 3308-4054

www.seer.ufrgs.br/ambienteconstruido

E-mail: ambienteconstruido@ufrgs.br 